\title{
Genotoxicity and activation of cellular defenses in transplanted zebra mussels Dreissena polymorpha along the Seine river
}

\author{
Châtel Amelie 1, 4, , Faucet-Marquis Virginie ${ }^{2}$, Gourlay-France Catherine ${ }^{1}$, Pfohl-Leszkowicz Annie ${ }^{2}$, \\ Vincent-Hubert Francoise ${ }^{1,3}$
}

\footnotetext{
${ }^{1}$ Cemagref, Unité de Recherche Hydrosystèmes et Bioprocédés, 1 rue Pierre-Gilles de Gennes, CS10030-92761 Antony, France

2 Université de Toulouse, INPT/ENSAT, Laboratoire de Génie Chimie, UMR-CNRS 5503, Département Bioprocédés et systèmes microbiens, 1 avenue agrobiopôle, 31320 Auzeville-Tolosane, France

3 IFREMER, Laboratoire de virologie, centre de Nantes, BP 21105, 44311 Nantes cedex 03, France

${ }^{4}$ Université Catholique de l'Ouest, Pôle recherche Département Sciences, 3 place André Leroy, BP10808, 49008 Angers Cedex 01, France
}

* Corresponding author : Amélie Châtel, email address : amelie.chatel@uco.fr

\begin{abstract}
:
The aim of the present study was to confirm the relevance of studying DNA adduct formation in a field study. In that context, freshwater mussels Dreissena polymorpha, collected in a reference station, were transplanted in different sites with a pollution gradient. After one and two months, mussels were collected and DNA adduct formation was analyzed using the ${ }^{32} \mathrm{P}$ post labelling technique on both gills and digestive glands. In addition, the expression of genes involved in the detoxification system (catalase (CAT), superoxide dismutase (SOD), glutathione S-transferase (GST), HSP70, aryl hydrocarbon receptor (AHR), P glycoprotein (PgP), metallothionein (MT)) was assessed by RT-PCR. DNA adducts were observed at amount comparable to data from literature. Increase of DNA adducts after two months of transplantation could be correlated with strong modulation of gene expression implicated in detoxification processes. Indeed, PgP and HSP70 gene expressions were similarly induced in gills and digestive glands while SOD and CAT expressions were down regulated in both tissues. AHR, GST and MT genes were differently regulated depending upon the tissue studied and the level of contamination in the different sites. We demonstrated that mussels transplanted in the different stations with pollution gradient were able to biotransform PAHs, assessed by DNA adduct formation and the high decrease of detoxification genes. Specific DNA adducts pattern obtained after one and two month mussel transplantations demonstrated the relevance of DNA adduct as biomarker of environmental pollution.
\end{abstract}




\section{Highlights}

- Dreissena polymorpha mussels were transplanted in polluted sites along the Seine river. - Expression of detoxification genes depended upon the tissue and the level of pollution. DDNA adducts were persistent for one and two months of exposure to pollutants. Mussels were able to detoxify PAHs assessed by the low DNA adduct level.

Keywords : Biomarker, Pollution, DNA adducts, Detoxification, Dreissena polymorpha, RT-PCR

\section{Introduction}

The freshwater mussel Dreissena polymorpha (Pallas, 1771) has been largely used for biomonitoring in lakes and in rivers ( Binelli et al., 2001, Guerlet et al., 2007, Bacchetta and Mantecca, $\underline{2009}$ and Bourgeault et al., 2010). Indeed, those animals present some advantages as bioindicator species: (i) they are sessile filter feeders capable of accumulating large amount of pollutants and especially metallic and hydrophobic contaminants such as polycyclic aromatic hydrocarbons (PAHs) ( Fisher et al., 1993 and Bourgeault et al., 2010); (ii) they are widespread along the world (Morton, 1997) and the Seine river ( Akopian et al., 2001); (iii) the fact that they live attached to rocky surfaces make the sampling easy. 
58 Seine basin is subjected to urban development since the last two centuries leading to an increase of metals and PAHs in water, derived from domestic, industrial wastewater and agricultural activities (Chevreuil and Garnier, 1991; Meybeck, 1998; Boët et al., 1999; Tusseau-Vuillemin et al., 2007). Some compounds, like PAHs, are metabolized by zebra mussels into electrophilic metabolites that have a high affinity to macromolecules such as DNA and form bulky DNA adducts (Le Goff et al., 2006). These bulky DNA adducts have been recognized to play a role in the initial step of chemical carcinogenesis in vertebrates (Van deer Oost et al., 1996; Pfohl-Leszkowicz, 2008).

In that context, so as to evaluate the impact of a contaminant mixture on biota health, molecular biomarkers have demonstrated their interest in biomonitoring studies. Biomarkers of DNA alteration (DNA strand breaks, micronuclei or DNA adducts) have been shown to be reliable indicators of genotoxic impact caused by pollutants, in zebra mussels (Rocher et al., 2006; Binelli et al., 2007; Bourgeault et al., 2010). Indeed, a few studies in fluvial or lake areas have underlined the interest of using DNA adducts (Pfohl-Leszkowicz et al 1993; LeGoff et al., 2006; Rocher et al., 2006; Al-Subiai et al., 2012; Cachot et al, 2013) and DNA strand breaks (Binelli et al. 2007; Jha, 2008; Michel et al., 2013) for biological effects evaluation of chemical contamination. DNA adducts formation was observed in both marine mussels (Akcha et al 2000 ; Skarpheoinsdottir et al., 2003; Pisoni et al., 2004; Amat et al, 2004; Bocquéné et al, 2004 ; Rocher et al., 2006) and freshwater mussels (LeGoff et al., 2006 and Rocher et al., 2006; Châtel et al., 2012), exposed to model PAHs which indicate that these species are able to metabolize benzo[a]pyrene $(\mathrm{B}[\mathrm{a}] \mathrm{P})$ into reactive metabolites that can bind to DNA and form DNA adducts. Moreover, field experiments have demonstrated a correlation between level of PAHs pollution and formation of DNA adduct in freshwater mussels (Le Goff et al., 2006; Rocher et al., 2006).

It has been highly described in Mammals that PAHs enter the cells through the Aryl hydrocarbon receptor (AHR) and then are metabolized by phase I and II enzymes. Very recently, a battery of genes implicated in biotransformation and detoxification processes were sequenced in D. polymorpha (Navarro et al., 2010; Contardo-Jara et al., 2011) : the glutathione S-transferase (GST), the phase I biotransformation enzyme ; the superoxide dismutase (SOD), responsible for the reduction of the superoxide radical to hydrogen 
oxygen (van der Oost et al., 2003; Bard, 2000); the HSP70 and the transmembrane protein transporter P-gp1, which acts as efluxing xenobiotics out of cells (Pain and Parant, 2003; 2007; Minier et al., 2006). In Invertebrates, metallothionein (MT) is also widely thought to play an important role in metal detoxification and in protecting cells against oxidative stress (Viarengo et al., 2000; Cavaletto et al., 2002). Rocher et al. (2006) have observed an induction of the antioxidant enzymes GST, catalase and SOD in gills of zebra mussels collected in sites along the Seine River compared to reference site and a clear relationship between SOD and GST activities and amounts of bioaccumulated metals and PAHs. Regoli and Principato (1995) have also demonstrated a strong induction of SOD and Gpx activities in M. galloprovincialis exposed to a complex mixture of metals in field conditions. Seasonal changes and especially temperature combined with pollution level in different collection sites were demonstrated to affect expression of genes encoding HSP70, SOD, MT in the oyster Crassostrea gigas (Farcy et al., 2007).

The aim of this study was to get an insight into the presence of DNA adduct in zebra mussels transplanted into Seine river sites along a pollution gradient so as to validate the interest of using DNA adduct as biomarkers of contamination in D. polymorpha. Because only few studies have compared the adduct levels in various tissues, we choose to compare those amounts in gills and digestive glands of zebra mussels. In order to confirm the persistence of DNA adduct observed in laboratory experiments (Châtel et al., 2012), mussels were transplanted into three sites of the Seine river and also on the reference site, which correspond to the sampling site, for 1 and 2 months. Moreover, expression of some genes implicated in phase I and II detoxification mechanisms as well as biomarkers involved in different metabolic pathways related to xenobiotic exposure were analysed in these mussels.

\section{Material and methods}

\section{Mussel sampling and maintenance conditions}

Adult zebra mussels Dreissena polymorpha (Pallas, 1771) 18-22mm long, were collected in Mars 2011 in a reference site Vertuzey (France) $\left(48^{\circ} 45^{\prime} 33^{\prime \prime} \mathrm{N}, 5^{\circ} 36^{\prime} 05^{\prime}\right.$ 'W). This site is located, far away from every city, not subjected to urban contamination, in the Meuse river North-eastern of France. Animals were transferred to laboratory, cleaned of all fouling organisms and kept in tank containing raw water originating from Vertuzey site $\left(16{ }^{\circ} \mathrm{C}\right)$ until field deployment.

\section{Mussel caging and study sites}


125 Mussels were placed into polyethylene 5mm-mesh experimental cages as previously 126 described (Bourgeault et al., 2010). Thirty mussels were transplanted for 1 or 2 months on each of the three sites of the Seine river basin (France) (Fig.1). Thirty mussels were also transplanted at the reference site of Vertuzey during the same time. The site of Marnay-surSeine was located $200 \mathrm{~km}$ upstream Paris while the two other sites, Bougival and Triel-surSeine were located downstream Paris and subjected to urban pollution as described in previous studies (Fernandes et al., 1997; Bourgeault et al., 2010). The site of Triel is subjected to both urban contamination and waste water discharge from domestic and industrial sewages. After one and two months of transplantation, mussels were collected; digestive glands and gills were dissected and stored at $-80^{\circ} \mathrm{C}$ for further analysis.

135

\section{${ }^{32}$ P postlabeling Analysis of DNA adducts}

\section{DNA isolation}

DNA isolation has been done as described by Pfohl-Leszkowicz \& Castegnaro 2005. In brief, digestive glands or gills were homogenized in a solution containing $\mathrm{NaCl}(0.1 \mathrm{M})$, EDTA (20 $\mathrm{mM})$ and Tris- $\mathrm{HCl}, \mathrm{pH} 8(50 \mathrm{mM})$ (SET). Proteins were precipitated by addition of SDS and of potassium acetate (6 M, pH 5). The supernatant, which contained nucleic acids, was collected and nucleic acids were precipitated overnight at $-20{ }^{\circ} \mathrm{C}$ by adding 2 volumes of cold ethanol. RNAs were eliminated following treatment by RNase A and RNase T1. Samples were then treated with proteinase $\mathrm{K}$ solution $\left(20 \mathrm{mg} / \mathrm{mL}\right.$ SET) for $1 \mathrm{~h}$ at $37{ }^{\circ} \mathrm{C}$. After digestion, DNA was extracted by rotiphenol (phenol saturated by Tris). The aqueous phase was collected after two extractions. After a final extraction with one volume of chloroform/isoamyl alcohol (24:1), the aqueous phase was collected. The DNA was precipitated by the addition of two volumes of cold ethanol overnight at $-20^{\circ} \mathrm{C}$. The purity of the DNA was checked by recording UV spectra at 220 and $320 \mathrm{~nm}$.

\section{${ }^{32} \mathrm{P}$ postlabeling}

DNA adducts were detected using the validated nuclease $\mathrm{P}_{1}$ enrichment method (Philipps \& Castegnaro, 1999) and the separation was done after contact transfer (Pfohl-Leszkowicz \& Castegnaro, 2005). In brief, DNA $(4 \mu \mathrm{g})$ was digested at $37^{\circ} \mathrm{C}$ for $4 \mathrm{~h}$ with $10 \mu \mathrm{L}$ of the mix containing of micrococcal nuclease and spleen phosphodiesterase. The digested DNA was then treated with nuclease $\mathrm{P} 1$ at $37{ }^{\circ} \mathrm{C}$ for $45 \mathrm{~min}$. The DNA adducts were labeled as follows. To the NP1 digest, $5 \mu \mathrm{L}$ of the reaction mixture containing $2 \mu \mathrm{L}$ of bicine buffer [Bicine (800 
$159 \mu \mathrm{M})$, dithiothreitol $(400 \mathrm{mM}), \mathrm{MgCl} 2(400 \mathrm{mM})$, and spermidine $(400 \mathrm{mM})$ adjusted to $\mathrm{pH}$ 1609.8 with $\mathrm{NaOH}], 9.6 \mathrm{U}$ of polynucleotide kinase $\mathrm{T} 4$, and $100 \mu \mathrm{Ci}$ of $\left[{ }^{32} \mathrm{P}\right] \mathrm{ATP}$ (specific activity $6000 \mathrm{Ci} / \mathrm{mmol}$ ) was added and incubated at $37{ }^{\circ} \mathrm{C}$ for $45 \mathrm{~min}$. Normal nucleotides, pyrophosphate, and excess ATP were removed by chromatography on PEI/cellulose TLC plates in $2.3 \mathrm{M} \mathrm{NaH}_{2} \mathrm{PO}_{4}$ buffer, pH 5.7, overnight (D1). The origin areas containing labeled adducted nucleotides were cut out and transferred to another PEI/cellulose TLC plate, which was run in 5.3 M lithium formate and $8.5 \mathrm{M}$ urea $(\mathrm{pH} 3.5)$ for $3 \mathrm{~h}$ (D2). A further migration was performed after turning the plate $90^{\circ}$ anticlockwise in $1 \mathrm{M} \mathrm{LiCl}, 0.5 \mathrm{M}$ Tris and $8 \mathrm{M}$ urea ( $\mathrm{pH}$ 8) for $2 \mathrm{~h}$ (D3). Finally, the chromatogram was washed in the same direction in $1.7 \mathrm{M}$ $\mathrm{NaH}_{2} \mathrm{PO}_{4}, \mathrm{pH} 6$, for $2 \mathrm{~h}$ (D4). The $\mathrm{N} 2 \mathrm{dG} \mathrm{B}[\mathrm{a}] \mathrm{P}$ adduct obtained during the EU project (Philipps and Castegnaro 1999) was run in the same conditions and serve as standard for quantification.

171 Radioactive spots were detected by autoradiography on Kodak super X-Ray film. 172 Autoradiography was carried out in the presence of an intensifying screen at $-80{ }^{\circ} \mathrm{C}$ for $48 \mathrm{~h}$. 173 (Amat-Bronnert et al., 2007). The radioactivity was measured by a phosphor imager as described below.

\section{Quantitation of total DNA Adducts}

177 For the quantification of total DNA adducts, the TLC plates were then placed in a storage 178 phosphor cassette containing a storage phosphor screen (Amersham) and exposed overnight. 179 Results are digitized using a storage phosphor imaging system (Typhoon ${ }^{\mathrm{TM}}$ 9210, Amersham) 180 and quantitated using ImageQuant ${ }^{\mathrm{TM}} 5.0$ software. After background subtraction, the levels of DNA adducts were expressed as relative adduct labelling (RAL) in total nucleotides. To calculate the levels of screen response (screen pixel) in dpm (disintegration per minute), samples of ${ }^{32} \mathrm{P}$-ATP at different concentrations from 10 to $500 \mathrm{dpm}$ were appropriately diluted and spotted on TLC plate. This TLC plate was then analysed on the Typhoon with the samples to obtain a radioactivity scale. The sensitivity allows detection of $\mathrm{B}[\mathrm{a}] \mathrm{P}$ adduct as low as 0.1 nucleotide/ $10^{10}$ nucleotides.

\section{RNA extraction, RT-PCR and quantitative RT-PCR analysis}

Total RNA from control and exposed mussels was extracted using TRIzol Reagent as described by Grebenjuk et al., 2002. RNA concentration and purity was measured by spectrophotometric absorption at 260 and $280 \mathrm{~nm}$. First strand cDNA synthesis was carried out on $1 \mu \mathrm{g}$ of total RNA extract with oligo-dT primers according to Improm II Reverse 
193 Transcriptase kit (Promega). Preparations of digestive glands and gills cDNA were used to 194 quantify specific transcripts in LightCycler 480 Real Time PCR System (Biorad) using SYBR 195 Green Power Master Mix (Invitrogen) with the specific primer pairs (Table 1). Relative 196 mRNA abundances of different genes were calculated from the second derivative maximum 197 of their respective amplification curves (Cp). Cp values for target genes (TG) were compared

198 to the corresponding values for a reference gene (ribosomal S3 gene) to obtain $\Delta \mathrm{Cp}$ values $199(\Delta \mathrm{Cp}=\mathrm{Cpref}-\mathrm{CpTG})$. PCR efficiency values for reference and tested genes were calculated 200 as described (Pfaffl, 2001). Results of gene expression from mussels collected in the different 201 sites were chosen to be compared to those of mussels from Vertuzey site as they were native 202 from this site; moreover this site is considered as the reference according to chemical analysis 203 (Michel et al., 2012).

204

\section{Statistical analysis}

206 Adduct and RT-PCR results are given as mean values \pm S.D. of 3 repetitions of each test 207 (10 mussels per condition pooled for DNA adduct analysis and 3 mussels per condition 208 pooled for RT-PCR measurements). The measured values were compared among different 209 locations using an Analysis of Variance (ANOVA) followed by a Tukey post hoc test. 210 Statistical significance was accepted at a $\mathrm{P}<0.05(*), \mathrm{P}<0.01(* *)$ and $\mathrm{P}<0.001(* * *)$. 


\section{Results}

\subsection{DNA adduct level}

213 An example of DNA adducts pattern is presented figure 2. Depending on the location, the

214 number of individual adducts ranged from 1 to 6 adducts. In reference location a faint adduct 215 numbered \#a, was observed, and does not correspond to the other adducts. Comparison of 216 DNA adducts pattern from the three sites on Seine river showed that pollutants were not the 217 same everywhere. One adduct (\#1) was present in the three locations, whereas the other ones 218 were specific to Marnay site (\# 5;6;7) or to Triel $(\# 2 ; 3)$. The adduct number \# 4 was 219 common to Bougival and Triel sites. Total DNA in gills and digestive glands are shown in figures $3 \mathrm{~A}$ and $3 \mathrm{~B}$ respectively.

Concerning the gills (Fig. 3A), highest amounts of total DNA adducts were detected in mussels encaged for 1 and 2 months in Bougival site (13.5 and 16.7 adducts $/ 10^{9}$ nucleotides, respectively). Mussels from Triel station depicted the lowest quantity of DNA adducts for both time exposure ( 3 and 5.2 adducts $/ 10^{9}$ nucleotides, respectively). After 2 months of caging, quantity of DNA adducts increased in mussels collected from the three different sites. As regard to mussels transplanted in Vertuzey site, they did not present any significant DNA adducts (below limit of quantification) for both time exposure tested.

The highest amounts of DNA adducts in digestive gland was detected in mussels transplanted to Marnay for one month (11.7 adducts $/ 10^{9}$ nucleotides). It is necessary to mention that this high amount was mainly due to one specific adduct (\# 7) observed at this site (Fig.3B). Higher amount of DNA adducts was observed in digestive gland of mussels from Triel site transplanted one month compared to Bougival site (6.8 versus 5.5 adducts $/ 10^{9}$ nucleotides, respectively). After 2 months of transplantation, a significative decrease of total amount of DNA adducts was observed at Marnay site, whereas it increased in Triel and Bougival sites.

\subsection{Gene expression}

In order to investigate some of the mechanisms of detoxification, we performed gene expression analysis in the freshwater zebra mussel using quantitative RT-PCR. S3 ribosomal gene was chosen as the reference gene for normalization as previously demonstrated (Contardo-Jara et al. 2010; Châtel et al. 2012).

In gills, after one month of transplantation, AHR mRNA expression was 10 times lower in mussels from Marnay, Bougival and Triel stations than those transplanted in 
Vertuzey site (reference site). The same tendency was observed in the digestive glands, as AHR mRNA expression was drastically reduced in mussels transplanted in the Seine river sites as compared to Vertuzey (Fig. 5 A).

On the contrary, after 2 months of caging, mRNA level in gills increased significantly in all mussels transplanted in the Seine river sites, with a seven times increase in animals transplanted at Bougival (Fig. 4A), compared to Vertuzey.

Concerning SOD gene, its expression was about 10 times decreased in gills and from 2 to 100 times in digestive glands in mussels encaged for 1 and 2 months in Marnay, Bougival and Triel compared to Vertuzey (Fig. 4 B; fig. 5 B).

The same profile was observed for CAT gene expression in gill of mussels which reduction was significant in all stations compared to control (Fig. $4 \mathrm{C}$ ). However, in the digestive glands, only a significant CAT induction (about 1.5 fold) was noticed after 2 months of caging in Triel compared to Vertuzey (Fig. 5 C).

GST mRNA level were only significant in gills of mussels from Marnay after 1 and 2 months (about 1.5 to 3 times). For all the other conditions, a significant decrease in GST expression was observed (Fig. 4 and 5 D).

P-gP gene expression was induced in gills of mussels encaged in Bougival after 1 and 2 months, and only after 1 month in digestive glands (Fig.4 E). The highest induction was in gills after one month of transplantation (9 times compared with Vertusey) (fig. $5 \mathrm{E}$ ). A slight induction of P-gP mRNA level was also observed in gills of mussels from Marnay following 1 month of caging and 2 months of caging in both tissues.

A slight induction in PgP mRNA level was also noticed in mussels transplanted in Triel after 2 months of caging. For all of the other time points, a significant decrease of P-gP expression was observed (Fig. 4 and 5 E).

As shown in figure 4 (F), HSP70 gene expression was significantly increased in gills of mussels encaged in all stations for 1 month, with the highest level observed for mussels collected in Marnay (4 fold increase compared to reference site). After 2 months of caging, a decrease of its expression was observed in gills of mussels collected in all stations, compared to Vertuzey. Digestive glands depicted the highest level of HSP mRNA in mussels encaged in Marnay and Triel for 1 months, with a 4 and 13 fold increase compared to reference site, 
279 respectively, whereas after 2 months, only an induction of HSP 70 mRNA expression was 280 noticed in digestive glands of mussels from Triel (16 fold increase compared to control 281 group) (Fig. 5 F).

282

283 Metallothionein gene expression was significantly decreased in all conditions tested 284 with the exception of a high induction in digestive glands of mussels transplanted in Marnay 285 and Triel for 2 months (Fig. 4 and 5 G). Interestingly, compared with others genes measured 286 in this study, the highest induction was observed with MT gene, with a 40 times induction in 287 the digestive glands of mussels transplanted at Marnay and Triel for 2 months (fig. $4 \mathrm{G}$ ). 288 


\section{Discussion}

In the present study, formation of bulky DNA adducts and induction of genes implicated in oxidative stress were investigated in zebra mussels D. polymorpha transplanted at sites with different amount of organic and metallic pollution along the Seine river (Tusseau-Vuillemin et al., 2007). This study aimed at getting a better understanding of the relationship between genotoxicants exposure and biological responses in terms of DNA damage and induction of genes implicated in detoxification mechanisms in transplanted mussels so as to demonstrate the suitability of measuring DNA adducts for genotoxicant monitoring in freshwater environments. All results obtained in this study are summarized in table 2 .

\section{DNA adduct formation}

DNA adducts are formed in gills and digestive glands of mussels transplanted either at the reference site of Vertuzey or at three contaminated sites along the Seine River, Marnay, Bougival and Triel. The total DNA adduct amount ranged from 3 to 16.7 adducts $/ 10^{9}$ nucleotides in gills and from 5.5 to 11.8 adducts $/ 10^{9} \mathrm{nt}$ in the digestive glands. The highest amount was measured in gills of mussels from Bougival (16.7 adducts $\left./ 10^{9} \mathrm{nt}\right)$, mainly due to one specific adduct. Skarphédinsdóttir et al. (2007) also showed higher levels of DNA adducts in gills of marine mussels exposed to PAHs in Nordic sea sites compared to digestive gland. Compared with other field studies, DNA adduct amount measured in this study was in the same range. Indeed, zebra mussels collected in the Seine estuary presented DNA adduct levels from 3.9 to $10 / 10^{9} \mathrm{nt}$ (Le Goff et al., 2006). In the same way, Rocher et al. (2006) also observed DNA adduct amounts in zebra mussels collected in stations from the Seine estuary and the Seine Bay around 10 adducts $/ 10^{9}$ nt.

The same range of DNA adduct formation was previously noticed in laboratory experiments where D. polymorpha exposed to Benzo[a]pyrene depicted DNA adducts ranging from 1.3 to 5.19 adducts $/ 10^{9}$ nucleotides in gills and from 0.9 to 2.29 adducts $/ 10^{9}$ nucleotides in the digestive glands (Châtel et al., 2012). This was also comparable to marine mussels exposed to the same xenobiotic (Canova et al., 1998; Skarpheoinsdottir et al., 2003; Akcha et al., 2000). Michel et al. (2013) observed that Bougival and Triel presented highest concentrations of PAHs in water in April and June compared to Marnay site, correlated with high concentration of PAHs in soft tissues, indicating that mussels were not able to detoxify those compounds. 
probably not exclusively related to PAHs. Some of specific adducts observed in Triel can be due to waste water sewage for example. Two adducts were only observed at Bougival and Triel and thus can be due to urban and industrial activities in Paris. DNA adducts are dependent upon many factors such as activity of the organism, feeding, lipid content and reproductive conditions (Skarpheoinsdottir et al., 2005) but also from biotransformation pathway (Pfohl-Leszkowicz, 2008). In addition, the balance between activating and detoxifying enzymes in cells such as glutathione S-transferase, cytochrome P450 have been demonstrated to vary seasonally (Kirchin et al., 1992; Wooton et al., 1996; Shaw et al., 2000; Rocher et al., 2006). Moreover, physico-chemical parameters such as temperature could also affect the reactivity of mussels to contaminants (Buschini et al., 2003).

In our study, we observed that DNA adduct pattern was similar and in the same range after 2 months of caging, except in Marnay site. If we only take into account the adduct \# 1 , which is common to the three sites, it appears that it increases at the both sites downstream Paris, whereas it decreases at Marnay. The specific adduct found in organs of mussels from Marnay could be due to other pollutants including pesticides or pharmaceuticals (Ginebreda et al, 2014). Globally, more individual adducts and higher amount of adduct \# 1 , which correspond to $\mathrm{B}(\mathrm{a}) \mathrm{P}$ adducts, are formed in digestive glands rather than in gills as mostly demonstrated in literature (Châtel et al., 2012; Skarpheoinsdottir et al., 2003). In a previous laboratory study, we demonstrated that zebra mussels induced a tissue-specific formation of DNA adducts after 5 days of $\mathrm{B}[\mathrm{a}] \mathrm{P}$ exposure and that levels were persistent 28 days after the end of exposure (Châtel et al., 2012). Skarpheoinsdottir et al. (2003) have proved that in Mytilus galloprovincialis gills exposed to PAHs, DNA adducts were persistent after 2 weeks of exposure (whereas PAHs tissue concentration was not detectable in gills at this time point) indicating the interest of measuring DNA adduct levels rather than PAHs bioaccumulation in tissues.

\section{Metabolism gene expression}

This study also investigated induction of gene expression of enzymes implicated in cellular defense processes that represent the initial steps of a cascade of events linking environmental insults to ecological impact (Van der Oost et al., 2003).

In gills, an increase in AHR and GST gene expressions was noticed. AHR (Aryl Hydrocarbon Receptor) is known to be recruited for biotransformation processes after exposure to PAHs 
compounds (Genevois et al, 1998; Pfohl-Leszkowicz 2008). Once activated, AHR translocated into the nucleus where it activated the expression of many genes implicated in detoxification processes such as CYP450 (Whitlock, 1999; Hankinson, 1993). PAHs metabolisation by CYP450 leads to the formation of reactive metabolites that covalently bind to DNA forming DNA adducts (Newbold and Brookes, 1976; Osborne et al., 1981 ; PfohlLeszkowicz, 2008). AHR expression was enhanced in gills of mussels collected in polluted sites suggesting the presence of PAHs contaminants in those sites, as measured in water (Michel et al., 2013). An induction of AHR expression was only detected in gills and not in digestive glands which could be explained by the fact that gills is the first tissue in contact with pollutants and could explain the high efficiency of gills to detoxify PAHs, assessed by lower DNA adducts, compared to digestive glands. In a previous laboratory experiment (Châtel et al., 2012), it has also been demonstrated a faster induction of AHR gene expression in gills compared to digestive gland.

GST gene expression was only induced in gills of mussels transplanted in the different sites. Glutathione S-transferase is a phase II enzyme that plays a role in the detoxification, by GSH conjugaison, of electrophilic xenobiotic compounds. In this study, it appeared probably that GST was precociously activated in digestive glands. Power and Sheehan (1996) have observed a higher GST activity in gills than in digestive glands depending on the season.

It appeared that both in gills and digestive glands, HSP70 and PgP gene expression were significantly increased whereas SOD and CAT gene expression were decreased. Tissue specific differences were depicted in AHR, GST and MT gene expression levels. Indeed, AHR and GST gene expression increased in gills and decreased in digestive glands while the contrary was noticed for MT expression. In gills, the most induced genes were AHR (14 fold), PgP (10 fold), HSP70 and GST (4 fold) genes while MT (40 fold), HSP70 (16 fold), PgP and CAT ( 2 fold) were more expressed in digestive glands.

All organisms from bacteria to mammals exposed to environmental stressors respond by synthetizing heat-shock protein (HSP70) (Schlesinger et al., 1982). HSP70 gene expression is implicated in protein repair, transport and protection from oxidative stress (Contardo-Jara et al., 2010).

Our results showed that HSP70 mRNA expression was strongly induced (4 fold and 16 fold increase compared to mussels from reference site) both in gills and digestive glands of $D$. polymorpha transplanted at different sites with pollution gradient, this can be explained by presence of xenobiotics such as PAHs. HSP70 protein expression was enhanced in marine 
mussels exposed to PAHs (Werner et al., 1998), with a correlation to the formation of DNA adducts and oxidative damage (Solé et al., 1996). Studies have demonstrated a variability of HSP70 induction/duration depending on the stressor (temperature, salinity, xenobiotic, metals...), dose, time of exposure and organisms. For example, in zebra mussels, an exposure to heavy metals induced a transient increase in HSP70 mRNA level after 1 day (Navarro et al., 2011) while exposure to $\mathrm{B}[\mathrm{a}] \mathrm{P}$ enhanced its induction from $12 \mathrm{~h}$ exposure and remained persistent for 28 days (Châtel et al., 2012). This increase in HSP70 mRNA levels could be due to the fact that this gene possesses an anti-oxidant response element to which the transcription factor Nrf2 binds as suggested in D. polymorpha for GST and CAT (ContadoJara and Wiegand, 2008).

However, in the present study, HSP70 mRNA expression was not correlated with the amount of PAHs present in the different stations measured previously in the laboratory (Michel et al., 2013). This may suggest that other parameters such as temperature and $\mathrm{pH}$ might also affect HSP70 mRNA level induction, as demonstrated in other field studies (Hamer et al., 2004).

The transmembrane P-glycoprotein (P-gP) was as well induced in both tissues from mussels transplanted in the different sites compared to reference site. $\mathrm{P}-\mathrm{gP}$ is a part of the multixenobiotic resistance (MXR) mechanism and has been demonstrated to be induced in response to xenobiotics and especially PAHs (Bard, 2000).

Our results showed an induction of $\mathrm{P}-\mathrm{gP}$ expression depending on the pollution gradient (Michel et al., 2013) (a higher amount in mussels from Bougival than Marnay). PgP has been demonstrated to be involved in excretion of PAHs from cells (Kurelec et al., 1995) and hence indicated the process by which the mussel eliminates the pollutants from its cells, suggesting a detoxification process in mussels transplanted. An up-regulation of P-gP mRNA was also observed after mussel exposure to the $\beta$-blocker metroprolol (Contardo-Jara et al., 2010) and to the propanolol (Franzellitti et al., 2011), thus demonstrating elimination process. However, for the severely contaminated site located at Triel (Michel et al., 2013), P-gP expression was lower. This can been explained by an induction of apoptosis, as they can be severely damaged by pollutants (Châtel et al., 2011), and also by a lower DNA adduct quantity compared to the two other sites.

Concerning the digestive glands, induction of CAT and MT gene expression was noticed in mussels collected in the different sites. Catalase is an antioxidant enzyme that catalyses the 
transformation of reactive oxygen species (ROS) into $\mathrm{H}_{2} \mathrm{O}$ and hence indicate that detoxification processes were strongly present in digestive glands of mussels transplanted in the severe contaminated site.

MTs are cysteine rich peptides that mainly occur in cytosol, nucleus and lysosomes. They are nonenzymatic proteins enable to bind to particular heavy metals. Tissues directly involved in metal uptake, storage and excretion such as gills and digestive glands have a high capacity to synthesize MTs (Sarkar et al., 2006). The high induction of MT gene in transplanted mussels suggests that mussels are exposed to heavy metal, indicating the presence of metals in water. The contamination by heavy metals has been largely described in the Seine river (Bourgeault et al., 2010, Tusseau-Vuillemin et al., 2007) and dissolved Cd has been measured to be around $37 \mathrm{ng} / \mathrm{L}$. It is interesting to notice that MT gene is induced in mussels exposed to such a low concentration of metal. Navarro et al. (2011) also demonstrated the strong induction of MT gene in zebra mussels exposed to low $\mathrm{Cd}, \mathrm{Cu}$ and $\mathrm{Hg}$ concentration $(20 \mu \mathrm{g} / \mathrm{L})$.

All those data strongly converge towards the fact that mussels were able to activate their detoxification mechanisms. However, this detoxification was not efficient enough to clear PAHs compounds bioaccumulated in the different stations, as shown by the high amounts of DNA adducts detected.

\section{Conclusion - Perspectives}

Field studies showed the complexity of environmental impacts on freshwater organisms, and made us realize about the importance of taking this into account to define new biomarkers. This study was performed to validate the suitability of using DNA adduct measurement in zebra mussels for genotoxicant monitoring of fresh water pollutants.

Our data highlighted the potential of the zebra mussel to detoxify pollutants. They also showed significant DNA adducts formation in both tissues, correlated to high presence of PAHs in water as in organisms (Michel et al., 2013). Moreover, a tissue specific induction of genes implicated in detoxification processes was demonstrated. Difference in DNA pattern allowed to confirm the presence of different kind of pollutants.

\section{Acknowledgements}

This work was supported by the PIREN-Seine program and the ONEMA (Office National de l'Eau et des Milieux Aquatiques). We declare no conflict of interests. 
459 


\section{References}

Al-Subiai, S.N., Arlt, V.M., Frickers, P.E., Readman, J.W., Stolpe, B., Lead, J.R., Moody, 462 A.J., Jha, A.N., 2012. Merging nano-genotoxicology with eco-genotoxicology: An integrated approach to determine interactive genotoxic and sub-lethal toxic effects of $C(60)$ fullerenes and fluoranthene in marine mussels, Mytilus sp. Mutation Research. 745, 92-103.

Akcha, F., Izuel, C., Venier, P., Budzinski, H., Burgeot, T., Narbonne, J.F., 2000. Enzymatic biomarker measurement and study of DNA adduct formation in benzo[a]pyrene contaminated mussels, Mytilus galloprovincialis. Aquatic Toxicology. 49, 269-287.

Akopian, M., Garnier, J., Testard, P. and Ficht, A., 2001. Estimating the Benthic Population of Dreissena polymorpha and Its Impact in the Lower Seine River, France. Estuaries. 24, 1003-1014.

Amat, A., Castegnaro, M., Burgeot, T. \& Pfohl-Leszkowicz, A., 2004. DNA adducts as a biomarker of pollution- Field study on the genotoxic impact evolution of the Erika oil spill on mussels (Mytilus edulis) over an eleven months period. Polycyclic aromatic compounds. 24, 713-732

Amat-Bronnert, A., Castegnaro, M., Pfohl-Leszkowicz, A., 2007. Genotoxic activity and induction of biotransformation enzymes in two human cell lines after treatment by Erika fuel extract. Environmental Toxicology and Pharmacology. 23(1), 89-95.

Bacchetta, R., Mantecca, P., 2009. DDT polluted meltwater affects reproduction in the mussel Dreissena polymorpha. Chemosphere. 76(10), 1380-1385.

Bard, S.M., 2000. Multixenobiotic resistance as a cellular defense mechanism in aquatic organisms. Aquatic Toxicology. 1, 357-389.

Binelli, A., Riva, C., Provini, A., 2007. Biomarkers in Zebra mussel for monitoring and quality assessment of Lake Maggiore (Italy). Biomarkers. 12, 349-68.

Binelli, A., Bacchetta, R., Vailati, G., Galassi, S., and Provini, A., 2001. DDT contamination

in Lake Maggiore (N. Italy) and effects on zebra mussel spawning. Chemosphere. 45(4-5), 409-415.

Bocquéné, G., Chanteraeu, S., Raffin, B., Minier, C., Clérendeau, C., Pfohl-Leszkowicz, A., Beausir, E., Narbonne, J.F., Burgeot, T. \& Ménard, D., 2004. Biological effects of the "ERIKA" oil spill on the common mussel (Mytilus edulis). Aquatic living ressources. 17(3), 309-316.

Boët, P., Belliard, J., Berrebi-dit-Thomas, R., Tales, E., 1999. Multiple human impacts by the City of Paris on fish communities in the Seine river basin, France. Hydrobiologia. 410,59-68.

Bourgeault, A., Gourlay-France, C., Vincent-Hubert, F., Palais, F., Geffard, A., BiagiantiRisbourg, S., Pain-Devin, S., Tusseau-Vuillemin, M.H., 2010. Lessons from a transplantation of zebra mussels into a small urban river: An integrated ecotoxicological assessment. Environmental Toxicology. 25, 468-78. 
506 Buschini, A., Carboni, P., Martino, A., Poli, P., Rossi, C., 2003. Effects of temperature on baseline and genotoxicant-induced DNA damage in haemocytes of Dreissena polymorpha. Mutation Research - Genetic Toxicology and Environmental Mutagenesis. 537(1), 81- 92.

Cachot, J., Cherel, Y., Larcher, T., Pfohl-Leszkowicz, A., Laroche, J., Quiniou, L., Morin, J., Schmitz, J., Burgot, T., Pottier, D., 2013. Histopathological lesions and DNA adducts in the liver of European Flounder (Platichthys flesus) collected in the Seine estuary versus two estuarine system on the french Atlantic coast. Environmental Science and Pollution Research. 20, $723-737$.

Canova, S., Degan, P., Peters, L.D., Livingstone, D.R., Voltan, R., Venier, P., 1998. Tissue dose, DNA adducts, oxidative DNA damage and CYP1A-immunopositive proteins in mussels exposed to waterborne benzo[a]pyrene. Mutation Research. 399, 17-30.

Cavaletto, M., Ghezzi, A., Burlando, B., Evangelisti, V., Ceratto, N., Viarengo, A., 2002. Effect of hydrogen peroxide on antioxidant enzymes and metallothionein level in the digestive gland of Mytilus galloprovincialis. Comparative Biochemistry and Physiology C Toxicology and Pharmacology. 131(4), 447-55.

Châtel, A., Faucet-Marquis,V., Perret,M., Gourlay-Francé, C., Uher,E., Pfohl-Leszkowicz, A., Vincent-Hubert,F., 2012. Genotoxicity assessment and detoxification induction in Dreissena polymorpha exposed to benzo[a]pyrene. Mutagenesis. 27(6),703-711.

Chevreuil, M., Granier L., 1991. Seasonal cycle of polychlorinated biphenyls in the waters of the catchment basin of the River Seine (France). Water, Air, and Soil Pollution. 59(3-4), 217229.

Contardo-Jara, V., Wiegand, C., 2008. Molecular biomarkers of Dreissena polymorpha for evaluation of renaturation success of a formerly sewage polluted stream. Environmental Pollution. 155, 182-9.

Contardo-Jara, V., Pflugmacher, S., Nutzmann, G., Kloas, W., Wiegand, C., 2010. The beta receptor blocker metoprolol alters detoxification processes in the non-target organism Dreissena polymorpha. Environmental Pollution. 158, 2059-66.

Farcy, E., Voiseux, C., Lebel, J.M., Fievet, B., 2007. Seasonal changes in mRNA encoding for cell stress markers in the oyster Crassostrea gigas exposed to radioactive discharges in their natural environment. Science of Total Environment. 374(2-3), 328-41.

Fernandes, M.B., Sicre, M.A., Boireau, A., Tronczynski, J., 1997. Polyaromatic hydrocarbon (PAH) distributions in the Seine River and its estuary. Marine Pollution Bulletin. 34, 857867.

Fisher, S.W., Gossiaux, D.C., Bruner, K.A. and Landrum P.F., 1993. Investigations of the toxicokinetics of hydrophobic contaminants $\mathrm{Cd}$ in the zebra mussel (Dreissena polymorpha) . Lewis Publishers, Boca Raton, U .S .A. pp. 465-490. 
Franzellitti, S., Buratti, S., Valbonesi, P., Capuzzo, A., Fabbri, E., 2011. The $\beta$-blocker propranolol affects cAMP-dependent signaling and induces the stress response in Mediterranean mussels, Mytilus galloprovincialis. Aquatic Toxicology. 101, 299-308.

Genevois, C., Pfohl-Leszkowicz, A., Boillot, K., Brandt, H. \& Castegnaro, M., 1998. Implication of Cytochrome P450 1A isoforms and the Ah receptor in the genotoxicity of coaltar fume condensate and bitume fumes condensates. Environmental Toxicology and Pharmacology. 5, 283-294

Ginebreda A., Kuzmanovic,M., Guash, H., Lopez de Alde, M., Lopez-Doval, J., Munoz,I., Ricart, M., Romani, AM., Sabater, S. Barcelo, D., 2014. Assessement of multi-chemical pollution in aquatic ecosystems using toxic units: Compound prioritization, mixture characterization and relationship with biological decriptors. Science of Total Environment. 468-469, 715-723.

Grebenjuk, V.A., Kuusksalu, A., Kelve, M., Schutze, J., Schroder, H.C., Muller, W.E., 2002. Induction of (2'-5')oligoadenylate synthetase in the marine sponges Suberites domuncula and Geodia cydonium by the bacterial endotoxin lipopolysaccharide. European Journal of Biochemistry. 269, 1382-92.

Guerlet, E., Ledy, K., Meyer, A., Giambérini, L., 2007. Towards a validation of a cellular biomarker suite in native and transplanted zebra mussels: A 2-year integrative field study of seasonal and pollution-induced variations. Aquatic Toxicology. 81(4), 377-388.

Hamer, B., Hamer, D.P., Muller, W.E., Batel, R., 2004. Stress-70 proteins in marine mussel Mytilus galloprovincialis as biomarkers of environmental pollution: a field study. Environmental International. 30, 873-882.

Hankinson, O., 1993. Research on the aryl hydrocarbon (dioxin) receptor is primed to take off. Archives of Biochemistry and Biophysics. 300, 1-5.

Jha, A.N., 2008. Ecotoxicological applications and significance of the comet assay. Mutagenesis. 23, 207-21.

Kirchin, M.A., Wiseman, A., Livingstone, D.R., 1992. Seasonal and sex variation in the mixed function oxygenase system of the digestive gland microsomes of the common mussel Mytilus edulis L. Comparative Biochemistry and Physiology. 1O1C, 81-91.

Kurelec, B., 1995. Reversion of the multixenobiotic resistance mechanism in gills of marine mussel Mytilus galloprovincialis by a model inhibitor and environmental modulators of P170glycoprotein. Aquatic Toxicology. 33, 93-103.

Le Goff, J., Gallois, J., Pelhuet, L., Devier, M.H., Budzinski, H., Pottier, D., André, V., Cachot, J., 2006. DNA adduct measurements in zebra mussels, Dreissena polymorpha, Pallas: Potential use for genotoxicant biomonitoring of fresh water ecosystems. Aquatic Toxicology. 79, 55-64.

Meybeck, M., 1998. Man and river interface: Multiple impacts on water and particulates chemistry illustrated in the Seine river basin. Hydrobiologia. 373-374, 1-20. 
Michel, C., Bourgeault, A., Gourlay-Francé, C., Palais, F., Geffard, A., Vincent-Hubert, F., 2012. Seasonal and PAH impact on DNA strand-break levels in gills of transplanted zebra mussels. Ecotoxicology and Environmental Safety. 92, 18-26.

601

602

603

604

605

606

607

608

609

610

611

612

613

614

615

616

617

618

619

620

621

622

623

624

625

626

627

628

629

630

631

632

633

634

635

636

637

638

639

640

641

642

643

644

Minier, C., Abarnou, A., Jaouen-Madoulet, A., Le Guellec, A.M., Tutundjian, R., Bocquené, G., Leboulenger, F., 2006. A pollution-monitoring pilot study involving contaminant and biomarker measurements in the Seine Estuary, France, using zebra mussels (Dreissena polymorpha). Environmental Toxicology and Chemistry. 25, 112-9.

Morton, B., 1997. The aquatic nuisance species problem: a global perspective and review. In: D'Itri, F.M., editor. Zebra mussels and aquatic nuisance species. Chelsea, MI: Ann Arbor Press, Inc. pp. 1-54.

Navarro, A., Faria, M., Barata, C., Pina, B., 2011. Transcriptional response of stress genes to metal exposure in zebra mussel larvae and adults. Environmental Pollution. 159, 100-7.

Pain, S., Parant, M., 2003. Multixenobiotic defense mechanism (MDMX) in bivalves. C. R. Biologie. 326, 659-72.

Pain, S., Parant, M., 2007. Identification of multixenobiotic defence mechanism (MXR) background activities in the freshwater bivalve Dreissena polymorpha as reference values for its use as biomarker in contaminated ecosystems. Chemosphere. 67, 1258-63.

Pfaffl, M.W., 2001. A new mathematical model for relative quantification in real-time RTPCR. Nucleic Acids Research. 29, 45.

Pfohl-Leszkowicz A., 2008. Formation, persistence \& significance of DNA adduct formation in relation to some pollutants from a board perspective. Advance in toxicology. 2, 183-240.

Pfohl-Leszkowicz, A., \& Castegnaro, M., 2005. Further arguments in favour of direct covalent binding of Ochratoxin A (OTA) after metabolic biotransformation. Food Additives \& Contaminants Suppl. 1, 75-87

Pfohl-Leszkowicz, A., Weber-Lofti, F., Masfaraud, J.F., Devaux, A., Laouedj, A., Guillemaut, P., Malaveille, C., Rether, B., Monod, G. \& Dirheimer, G., 1993. DNA adduct detection: some applications to monitor exposure to environmental genotoxic chemicals. IARC Scientific Public., 124("Postlabelling methods for detection of DNA adducts"). 373378.

Philipps, D.H., Castegnaro, M., 1999. Standardization and validation of DNA adduct postlabelling methods: report of interlaboratory trials and production of recommended protocols. Mutagenesis. 14, 301-315.

Pisoni, M., Cogotzi, L., Frigeri, A., Corsi, I., Bonacci, S., Iacocca, A., Lancini, L., Mastrototaro, F., Focardi, S., Svelto, M., 2004. DNA adducts, benzo(a)pyrene monooxygenase activity, and lysosomal membrane stability in Mytilus galloprovincialis from different areas in Taranto coastal waters (Italy). Environmental Research. 96, 163-175. 
Power, A., Sheehan, D., 1996. Seasonal variation in the antioxidant defence systems of gill and digestive gland of the blue mussel, Mytilus edulis. Comparative Biochemistry and Physiology C. 114, 99- 103.

Prevodnik, A., Lilja, K., Bollner, T., 2007. Benzo[a]pyrene up-regulates the expression of the proliferating cell nuclear antigen (PCNA) and multixenobiotic resistance polyglycoprotein (Pgp) in Baltic Sea blue mussels (Mytilus edulis L.). Comparative Biochemistry and Physiology

C. Toxicology and Pharmacology. 145, 265-74.

Regoli, F., Principato, G., 1995. Glutathione, glutathione-dependent and antioxidant enzymes in mussel, Mytilus galloprovincialis, exposed to metals under field and laboratory conditions: implications for the use of biochemical biomarkers. Aquatic Toxicology. 31, 143-164.

Rocher, B., Le Goff, J., Peluhet, L., Briand, M., Manduzio, H., Gallois, J., Devier, M.H., Geffard, O., Gricourt, L., Augagneur, S., Budzinski, H., Pottier, D., Andre, V., Lebailly, P., Cachot, J., 2006. Genotoxicant accumulation and cellular defence activation in bivalves chronically exposed to waterborne contaminants from the Seine River. Aquatic Toxicology. 79, 65-77.

663 Sarkar, A., Ray, D., Shrivastava, A.N., Sarker, S., 2006. Molecular Biomarkers: their significance and application in marine pollution monitoring. Ecotoxicology. 15(4), 333-40.

666

Schlesinger, M.J., Ashburner, M., Tissieres, A., 1982. Heat-Shock from bacteria to Men. Cold Spring Harbor Laboratory : New York, 1982, 286p.

Seo, Y.R., Jung, H.J., 2004. The potential roles of p53 tumor suppressor in nucleotide excision repair (NER) and base excision repair (BER). Experimental and Molecular Medicine. 36, 505-9.

Shaw, J. P., Large, A. T., Chipman, J. K., Livingstone, D. R., Peters, L. D., 2000. Seasonal variation in mussel Mytilus edulis digestive gland cytochrome P4501A- and $2 \mathrm{E}$ immunoidentified protein levels and DNA strand breaks (Comet assay). Marine Environmental Research. 50(1-5), 405-409.

Skarphéinsdóttir, H, Ericson, G, Dalla Zuanna, L, Gilek, M., 2003. Tissue differences, doseresponse relationship and persistence of DNA adducts in blue mussels (Mytilus edulis L.) exposed to benzo[a]pyrene. Aquatic Toxicology. 62, 165-177.

Skarphéinsdóttir, H. G., Ericson, H., Halldórsson, P., Svavarsson, J., 2005. Seasonal and intertidal impact on DNA adduct levels in gills of blue mussels (Mytilus edulis L.). Environmental Pollution. 136(1), 1-9.

Skarphédinsdóttir, H., Ericson, G., Svavarsson, J., Naes, K. 2007. DNA adducts and polycyclic aromatic hydrocarbon (PAH) tissue levels in blue mussels (Mytilus spp.) from Nordic coastal sites. Marine Environmental Research. 64(4),479-91. Effects of the 'Aegean Sea' oil spill on biotransformation enzymes, oxidative stress and DNA-adducts in digestive gland of the mussel (Mytilus edulis L.). Comparative Biochemistry and Physiology. 113, 257-265. 
694 Tusseau-Vuillemin, M.-H., Gourlay, C., Lorgeoux, C., Mouchel, J.-M., Buzier, R., Gilbin, R., 695 Seidel, J.-L., Elbaz-Poulichet, F., 2007. Dissolved and bioavailable contaminants in the Seine river basin. Science of Total Environment. 375 (1-3), 244-256.

Van der Oost, R., Goksøyr, A., Celander, M., Heida, H., Vermeulen, N. P. E., 1996. Biomonitoring of aquatic pollution with feral eel (Anguilla anguilla) II. Biomarkers: pollution-induced biochemical responses. Aquatic Toxicology. 36 (3-4), 189-222.

Van der Oost, R., Beyer, J., Vermeulen, N.P.E., 2003. Fish bioaccumulation and biomarkers in environmental risk assessment: a review. Environmental Toxicology and Pharmacology.

704 13, 57-149.

705

706

Viarengo, A., Burlando, B., Ceratto, N., Panfoli, I., 2000. Antioxidant role of metallothioneins: a comparative overview. Cellular and Molecular Biology. 46(2), 407-17.

Werner, E.E., 1998. Ecological experiments and a research program in community ecology. In Experimental ecology: issues and perspectives. Resetarits, W.J.J. and Bernardo, J., editors. Oxford University Press, Oxford, UK. pp. 3-26

Whitlock, J.P., Jr., 1999. Induction of cytochrome P4501A1. Annual Review of Pharmacology and Toxicology. 39, 103-25.

Wootton, A.N., Goldfarb, P.S., Lemaire, P., O'Hara, S.M., Livingstone, D.R., 1996. Characterisation of the presence and seasonal variation of a CTP1A-like enzyme in digestive gland of the common mussel, Mytilus edulis. Marine Environmental Research. 42, 297-301. 
Table 1.Primer sequences (5'-3') used in qRT-PCR

Fig. 1. Localization of sampling sites along the Seine river basin.

Fig.2. Example of DNA adduct pattern of D. polymorpha transplanted in Vertuzey, Marnay, Bougival and Triel sites. The numbering of the individual adduct is depicted in the schemes.

Fig.3. Total DNA adduct in gills (A) and digestive glands (B) of D. polymorpha transplanted in Vertuzey, Marnay, Bougival and Triel sites for one or two months

Fig.4. Relative mRNA abundance values of AHR (A), SOD (B),CAT (C), GST (D), PgP (E), HSP70 (F) and MT (G) in gills of D. polymorpha transplanted in Vertuzey, Marnay, Bougival and Triel sites for one or two months, analysed by qRT-PCR. Results are normalised with the reference gene S3. $(*)$ : data significantly different compared to Vertuzey $(\mathrm{p}<0.05)$.

Fig.5. Relative mRNA abundance values of AHR (A), SOD (B),CAT (C), GST (D), PgP (E), HSP70 (F) and MT (G) in digestive gland of D. polymorpha transplanted in Vertuzey, Marnay, Bougival and Triel sites for one or two months, analysed by qRT-PCR. Results are normalised with the reference gene S3. $\left.{ }^{*}\right)$ : data significantly different compared to Vertuzey $(\mathrm{p}<0.05)$.

Table 2. Comparison of biomarker responses between gills and digestive glands of mussels transplanted in different sites along the Seine river 
Table 1.

\begin{tabular}{|l|l|l|l|l|}
\hline Gene & Short name & Forward primer & Reverse primer & Accession number \\
\hline Ribosomal protein S3 & S3 & CAGTGTGAGTCCCTGAGATACAAG & AACTTCATGGACTTGGCTCTCTG \\
\hline P-glycoprotein & P-gp1 & CACCTGGACGTTACCAAAGAAGATATA & TCACCAACCAGCGTCTCATATTT \\
\hline Aryl-hydrocarbon receptor & AHR & ATCACAGCGATGAGCCTCAG & AGACAGCATTGCGAGGTCAC & AJ506742 \\
\hline Superoxide dismutase & SOD & GACAGCATGGCTTCCATGTG & AGGAGCCCCGTGAGTTTG & DQ159188 \\
\hline Catalase & CAT & ATCAGCCTGCGACCAGAGAC & GTGTGGCTTCCATAGCCGTT & AY377970 \\
\hline Glutathione S-transferase & GST & ATGATCTATGGCAACTATGAGACAGG & GAAGTACAAACAGATTGTAGTCCGC \\
\hline Heat-shock Protein 70 & HSP70 & GCGTATGGACTTGATAAGAACCTCA & GAACCCTCGTCGATGGTCA & EF194203 \\
\hline
\end{tabular}

Fig. 1.

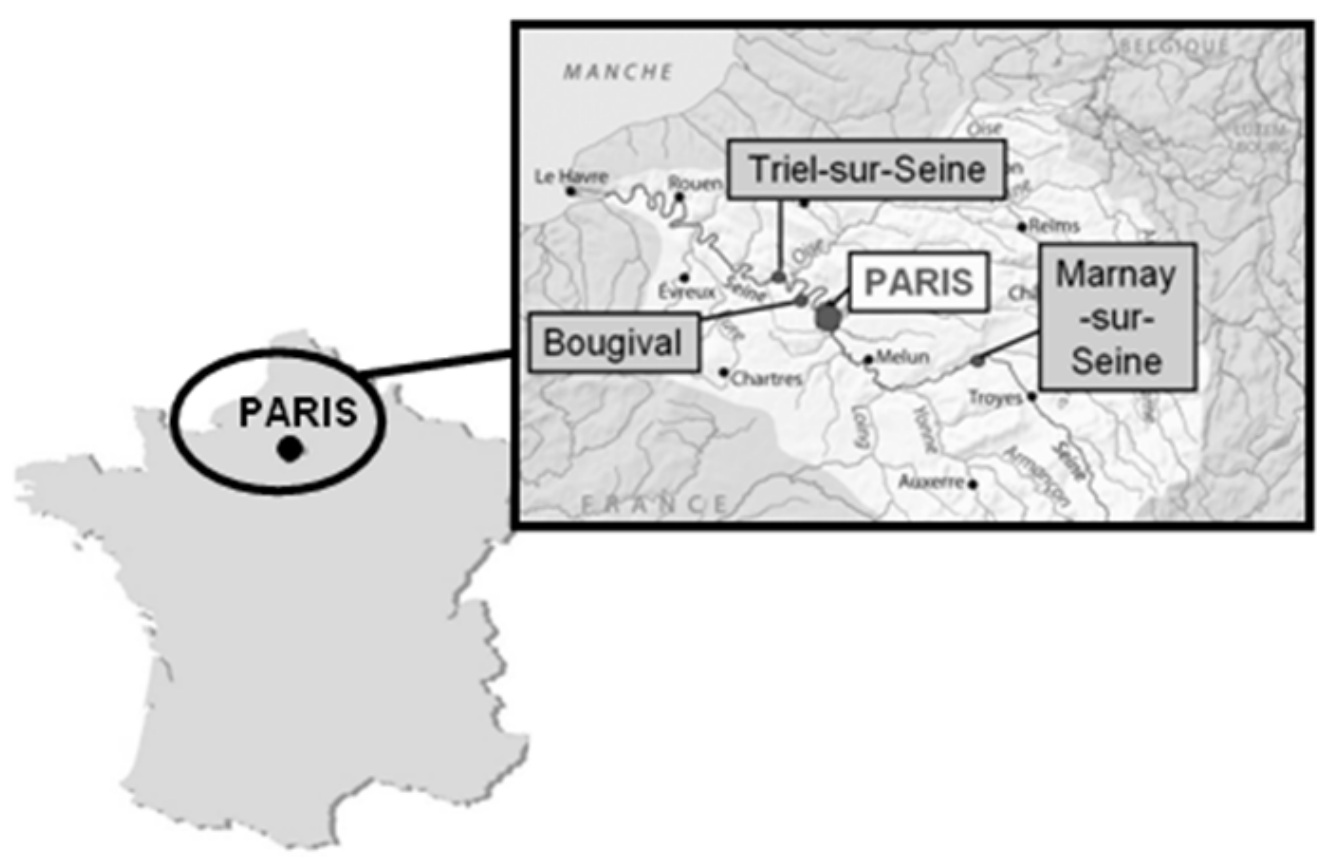


Fig.2

VERTUZEY
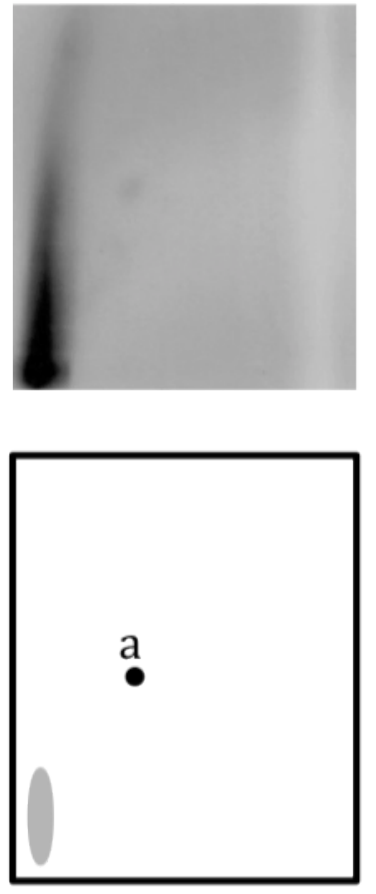

MARNAY
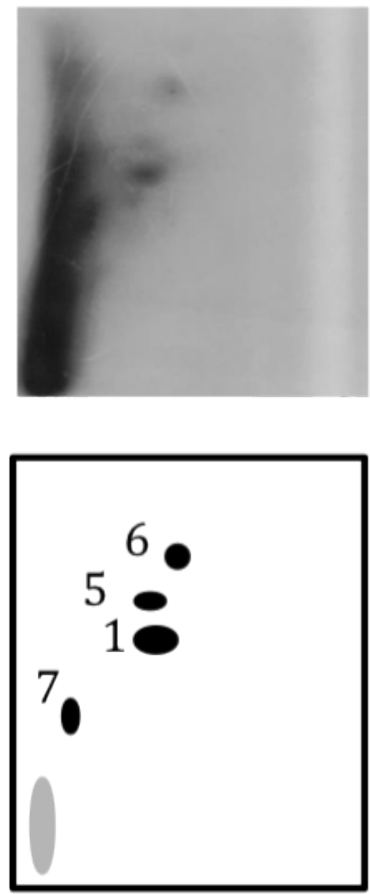

BOUGIVAL
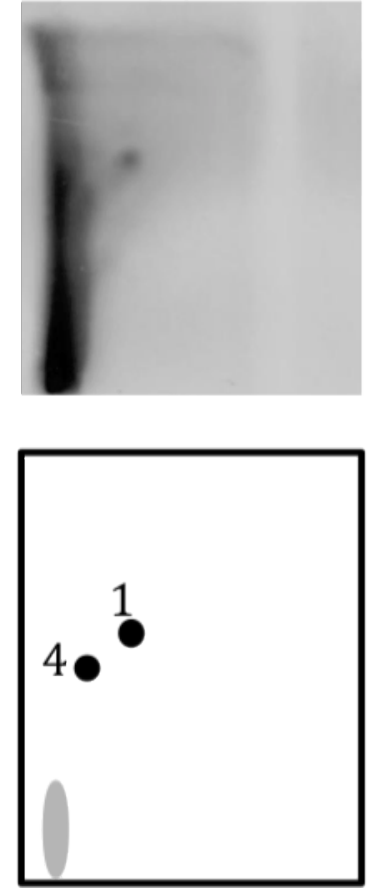

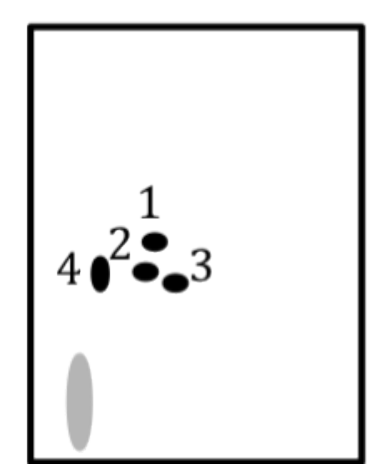

TRIEL

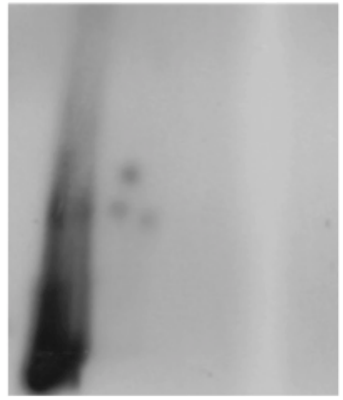


Fig.3
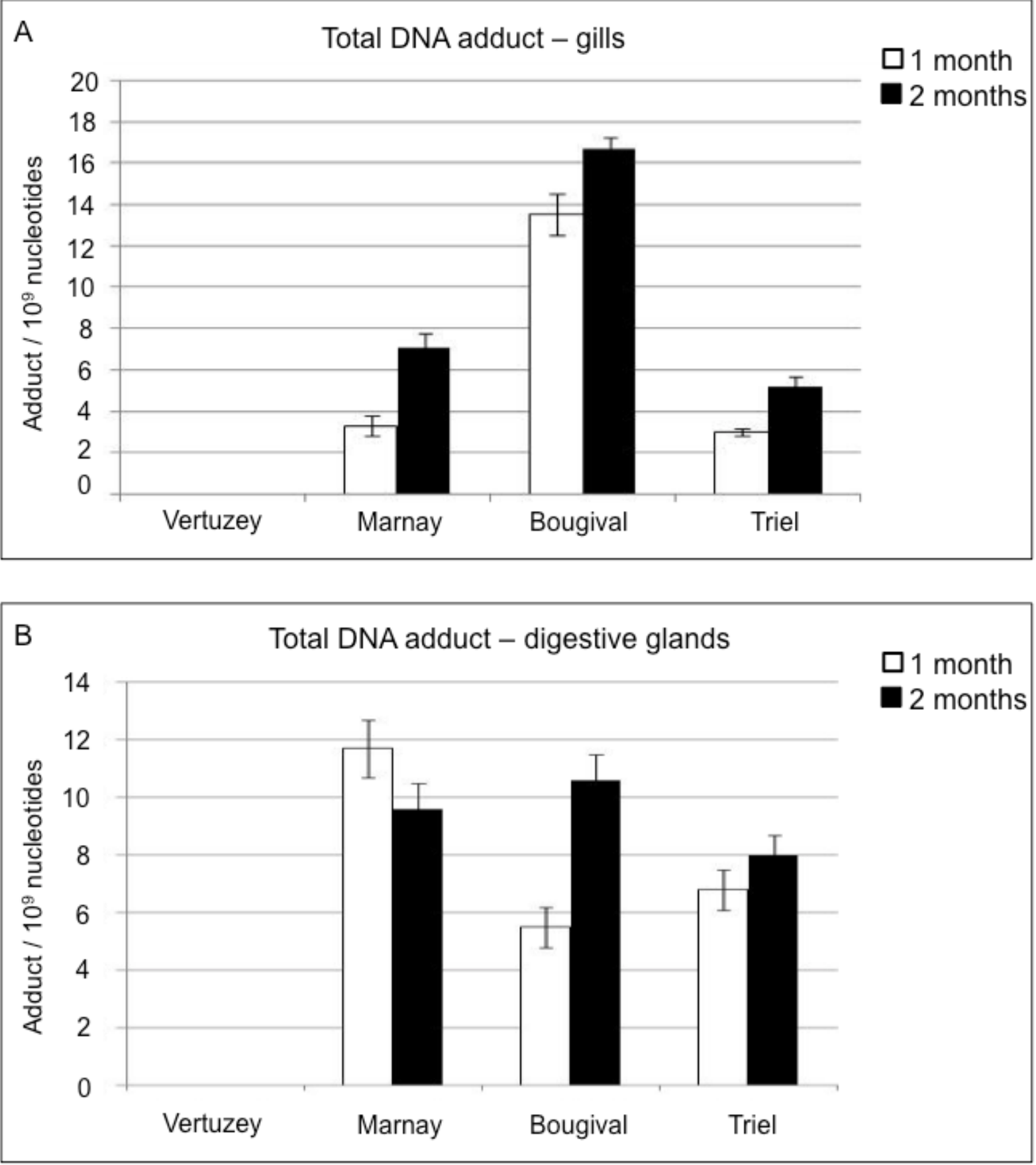
Fig.4

A.

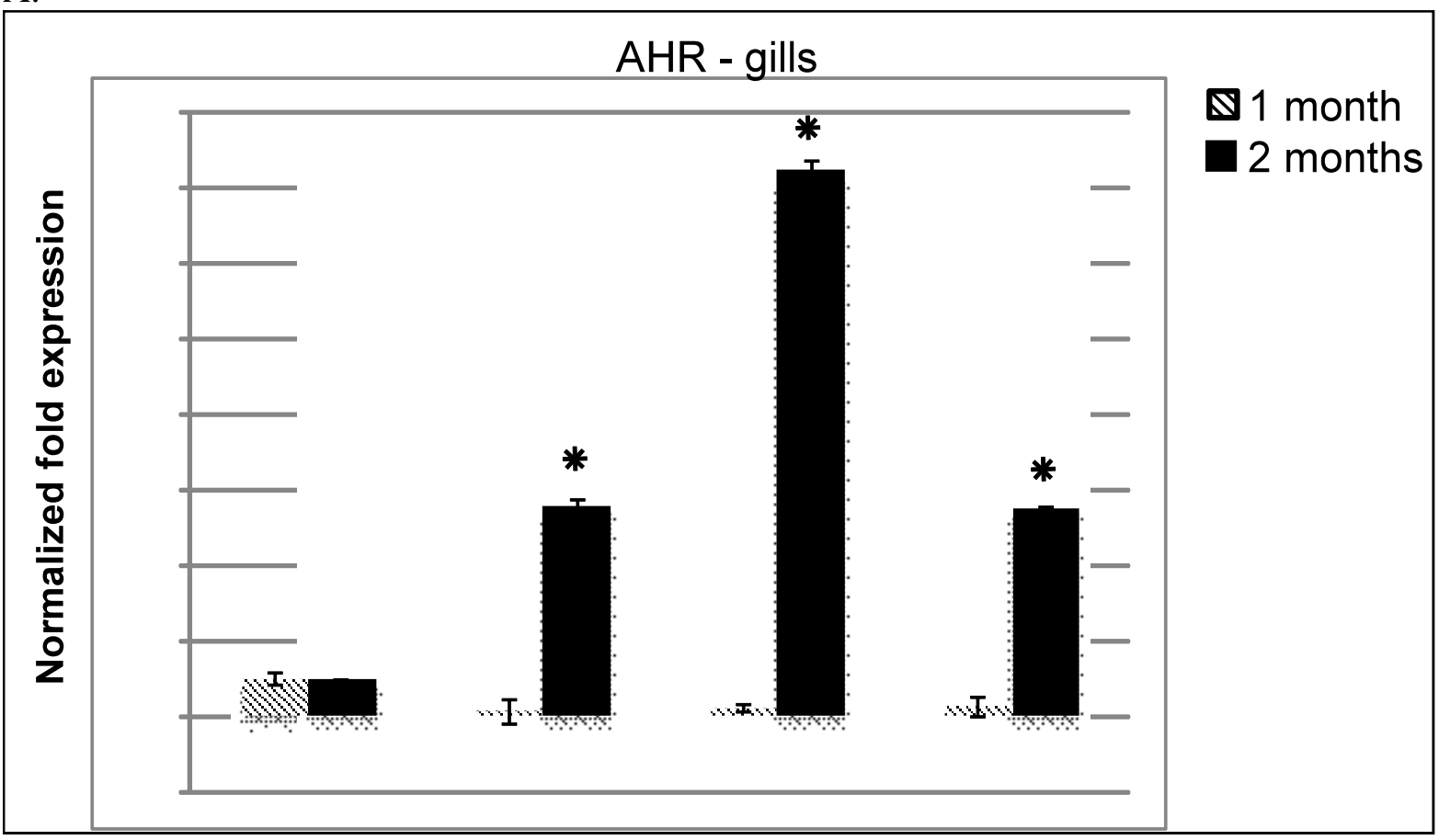

B.

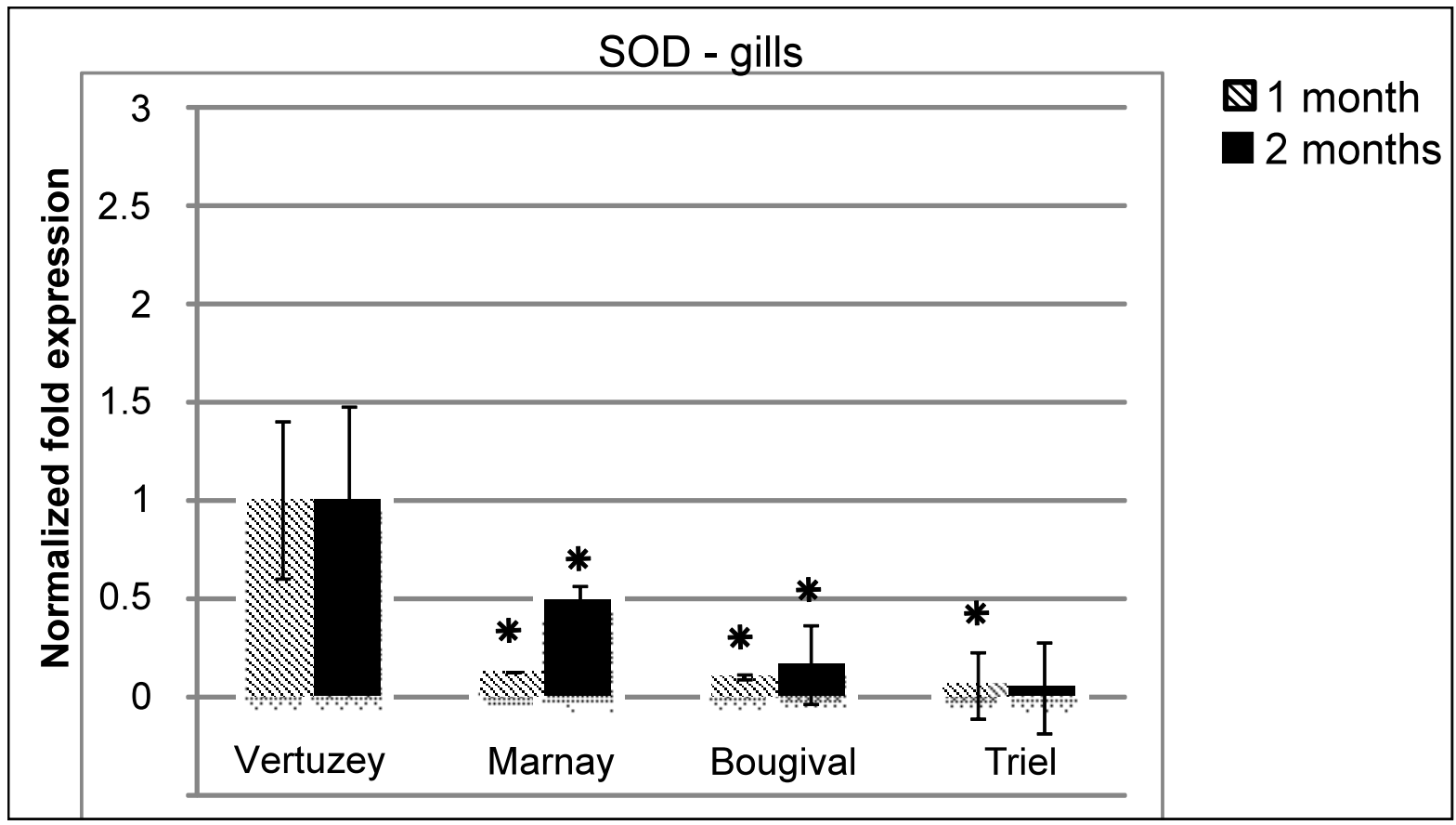

C. 


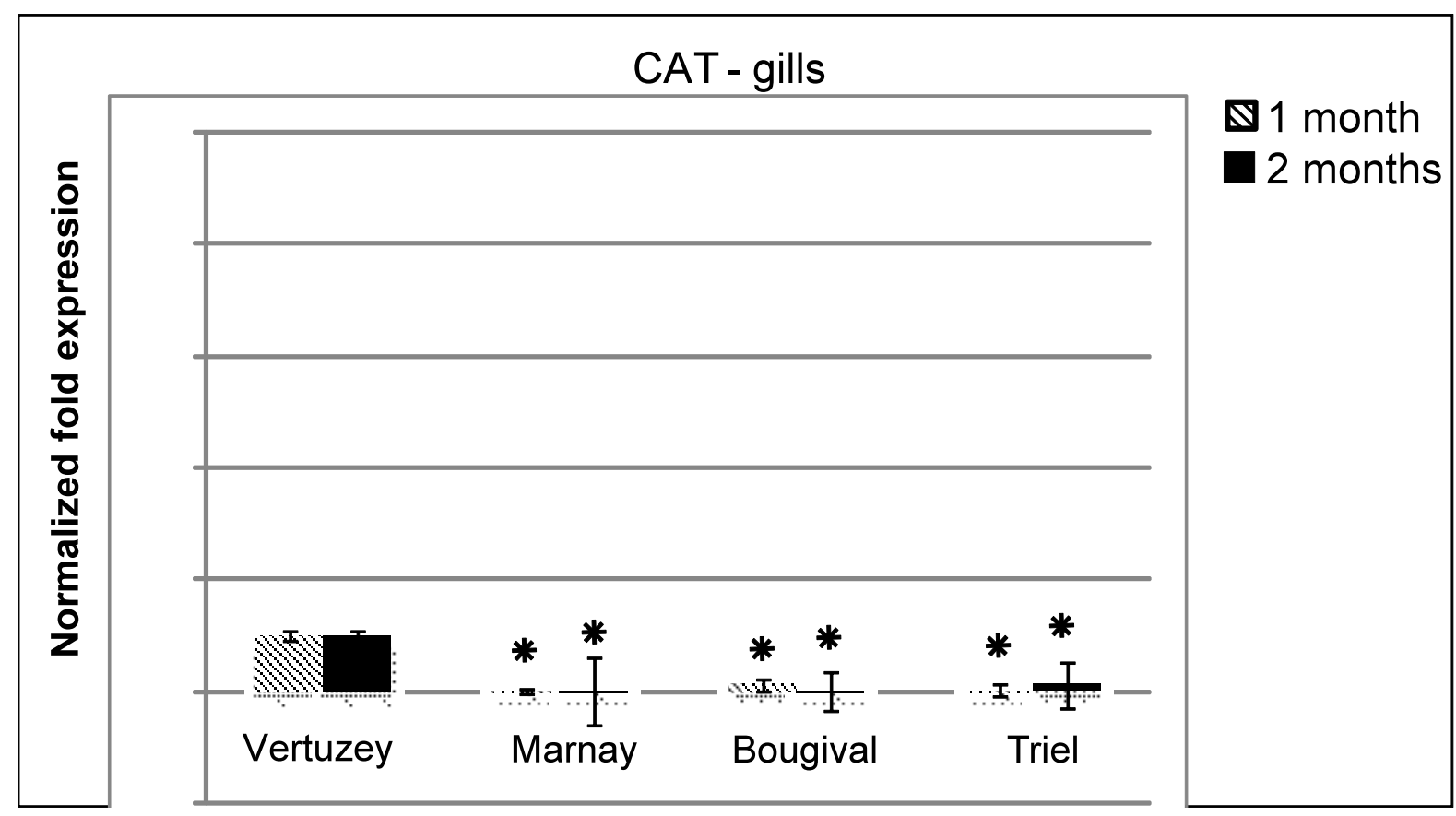

D.

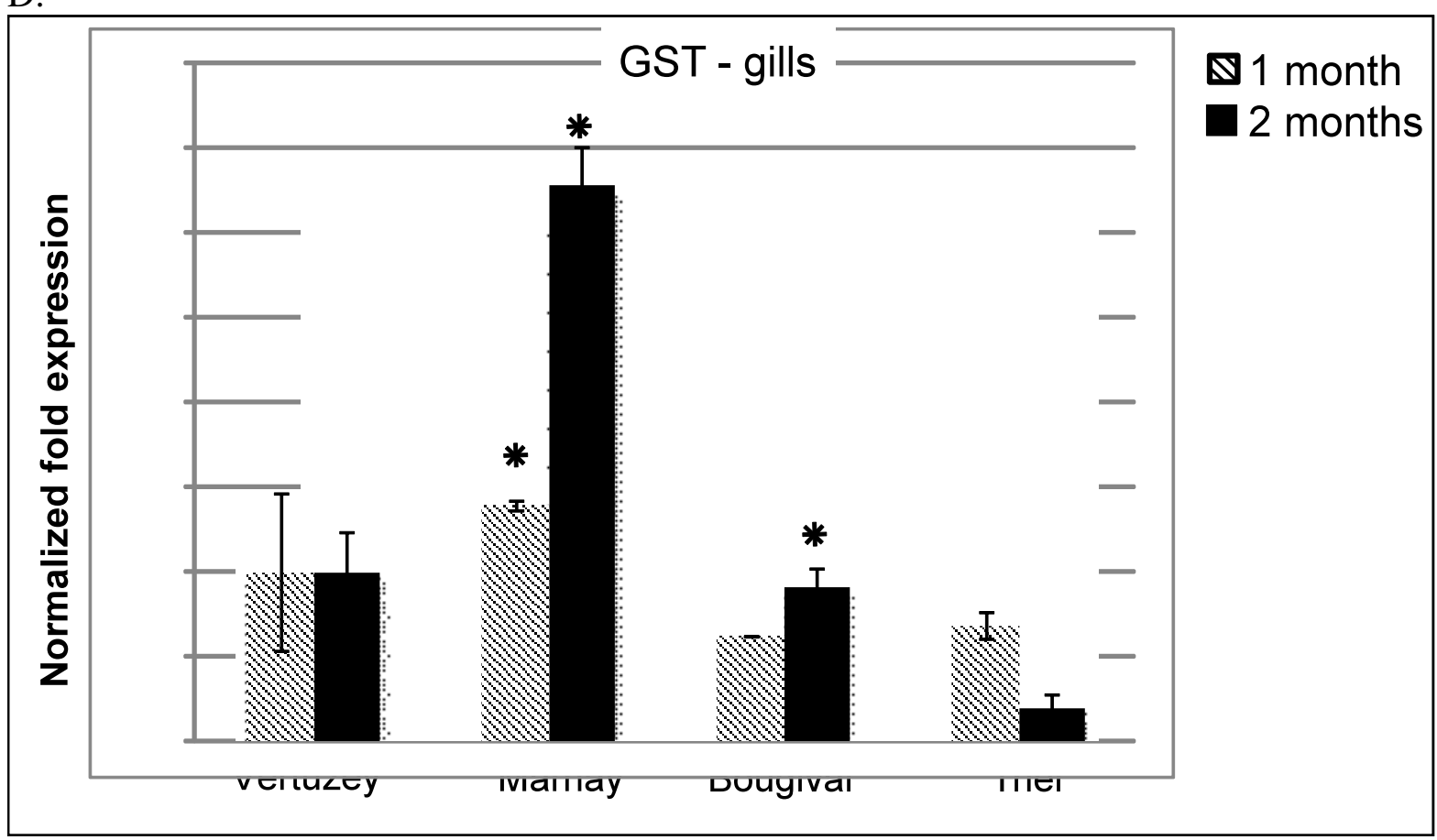

E. 


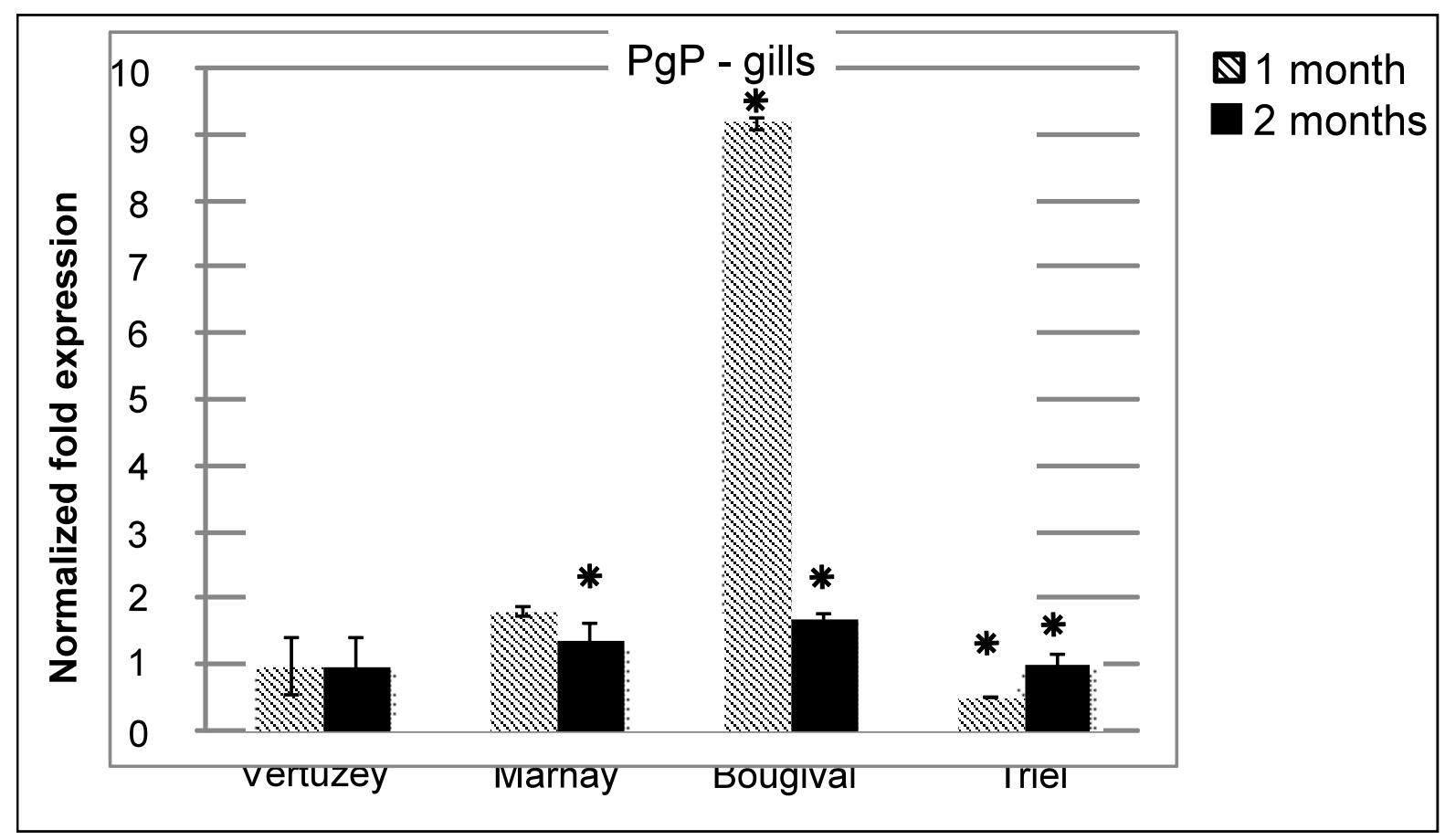

F.

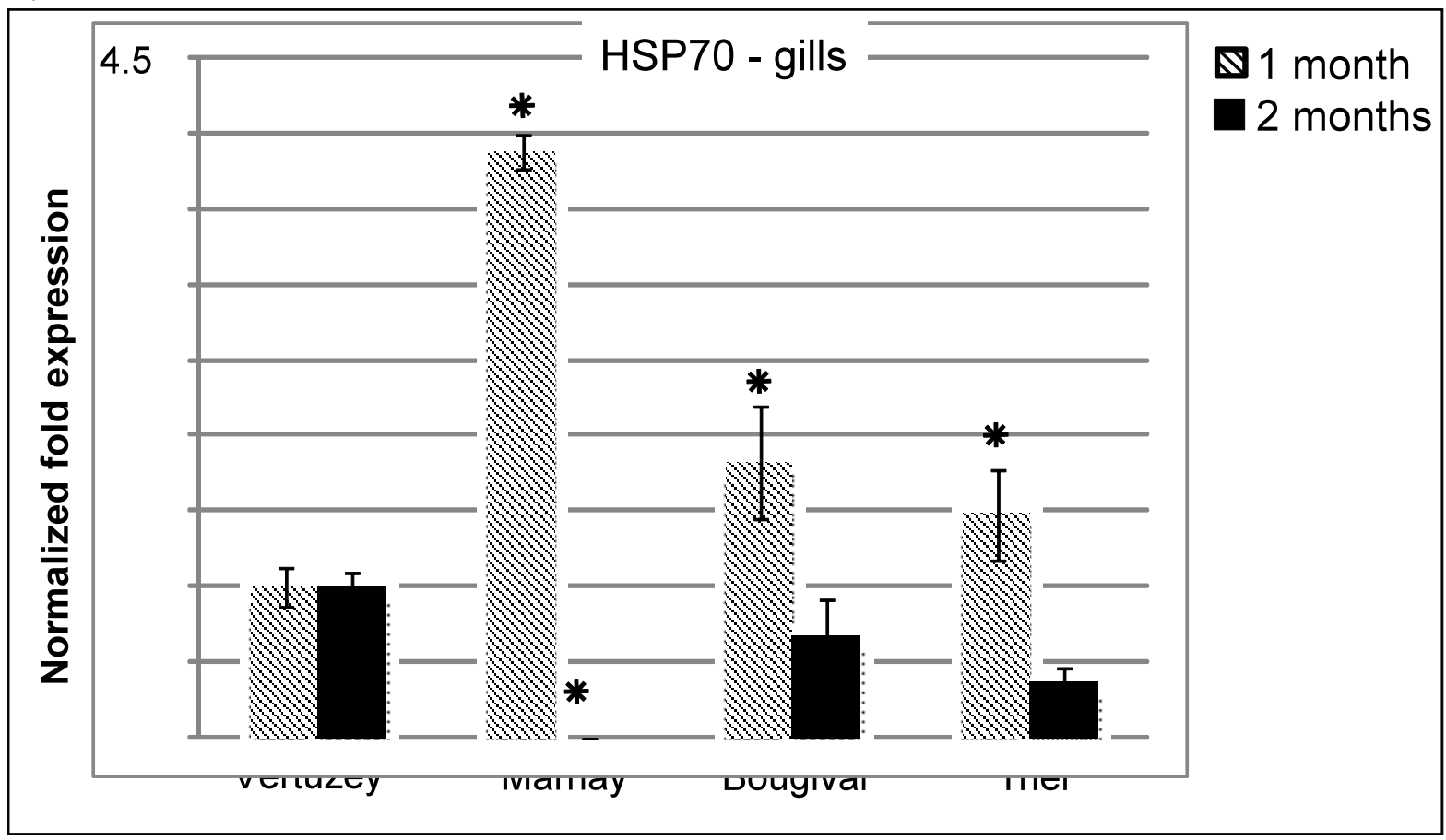

G. 


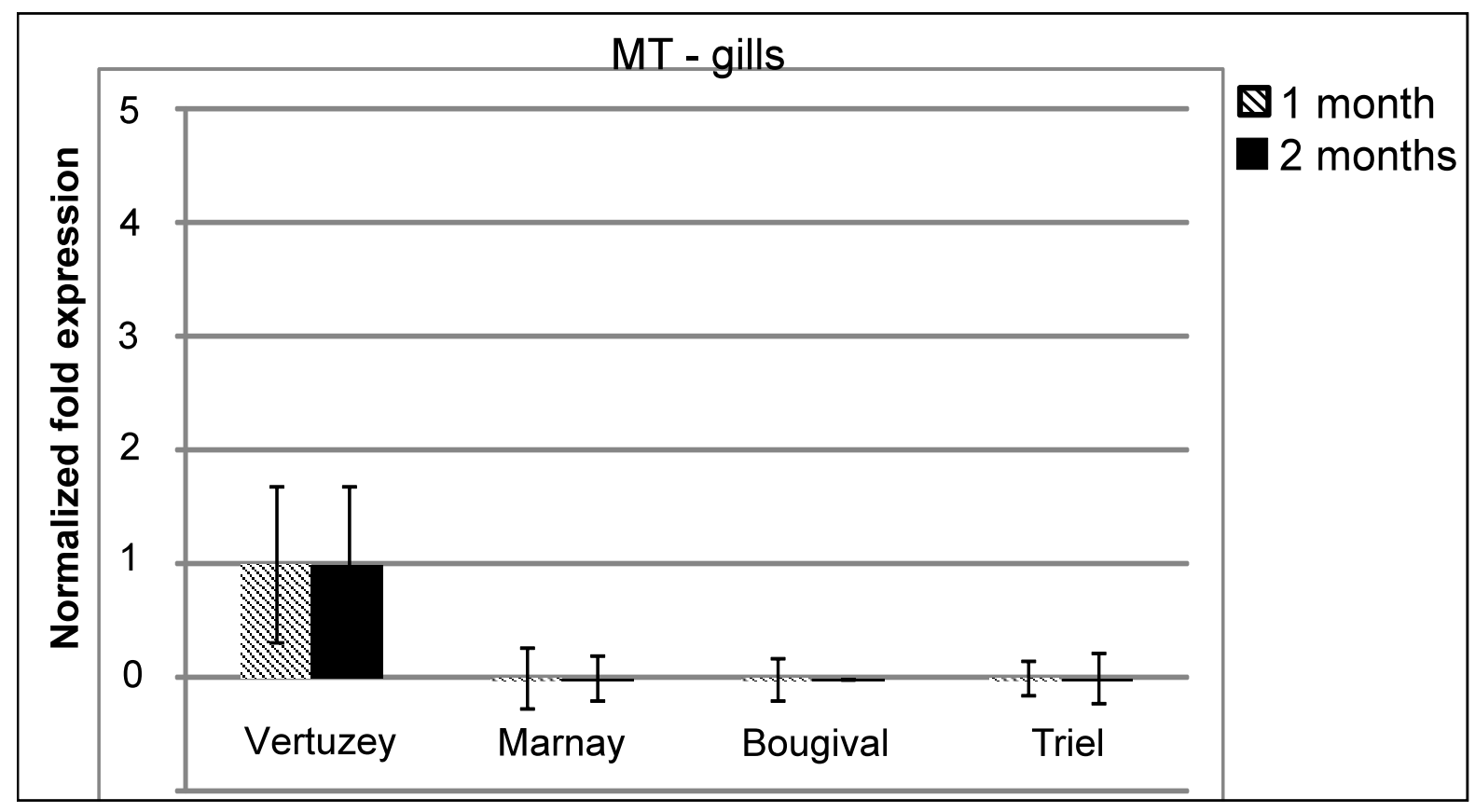

Fig.5.

A.

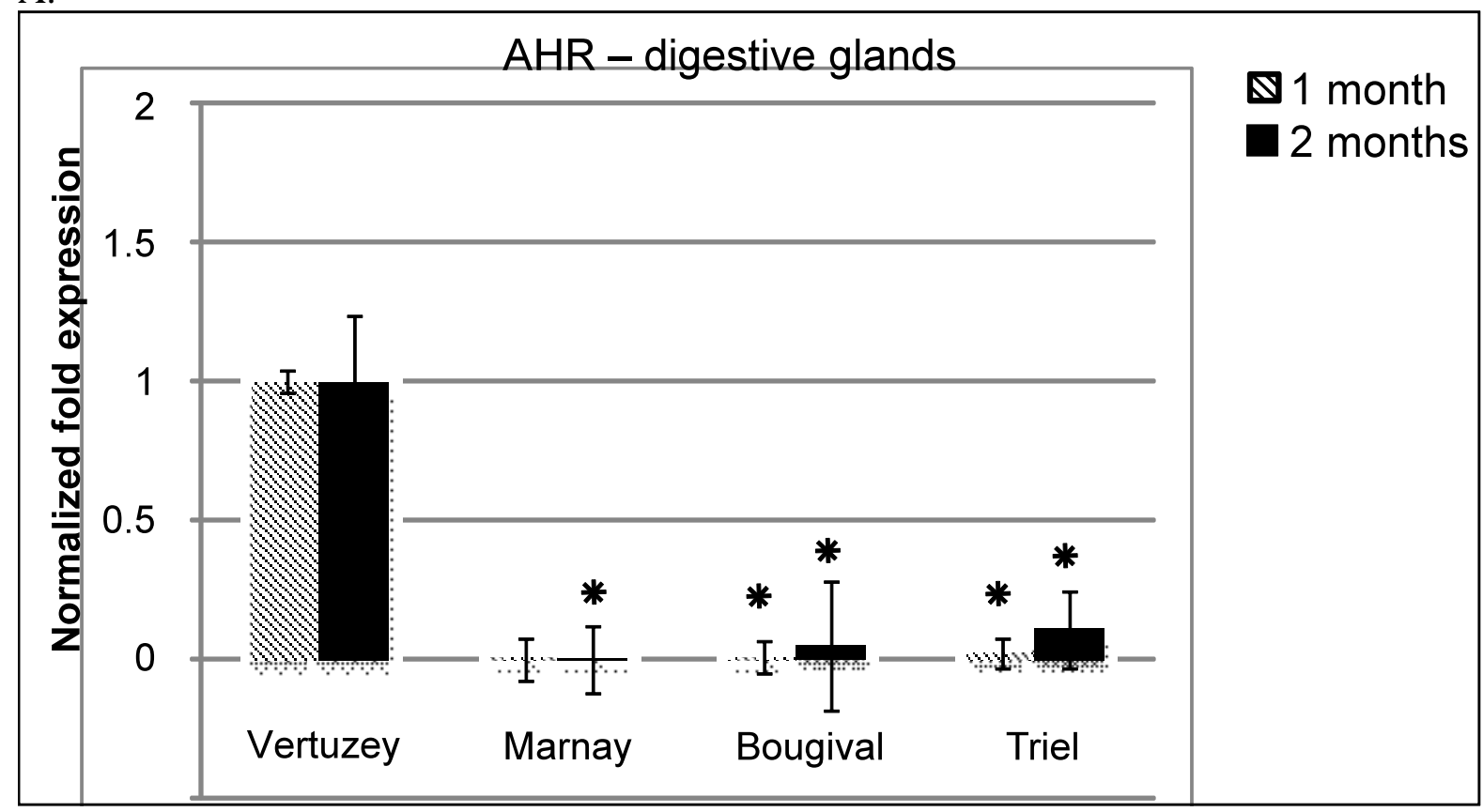

B. 


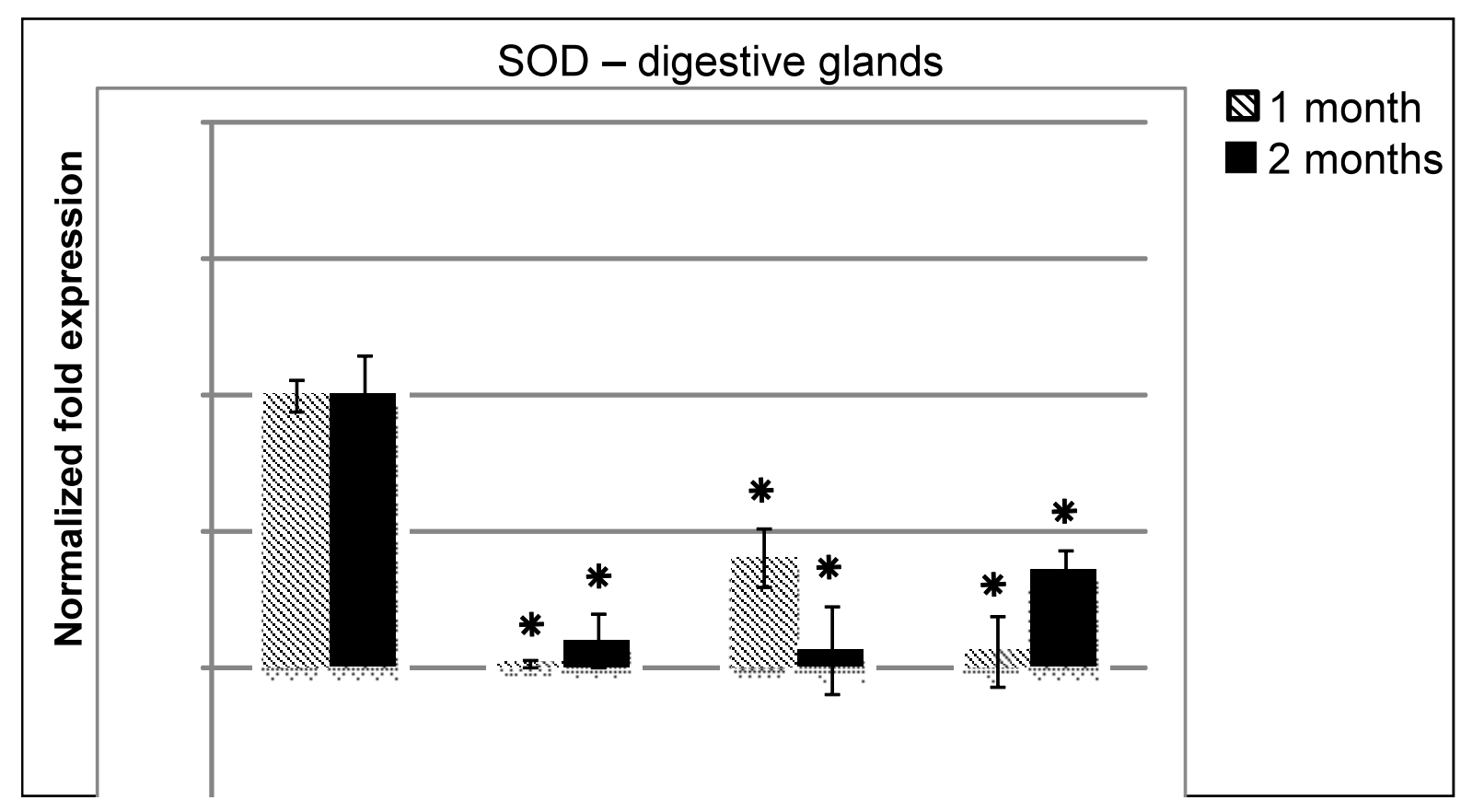

C.

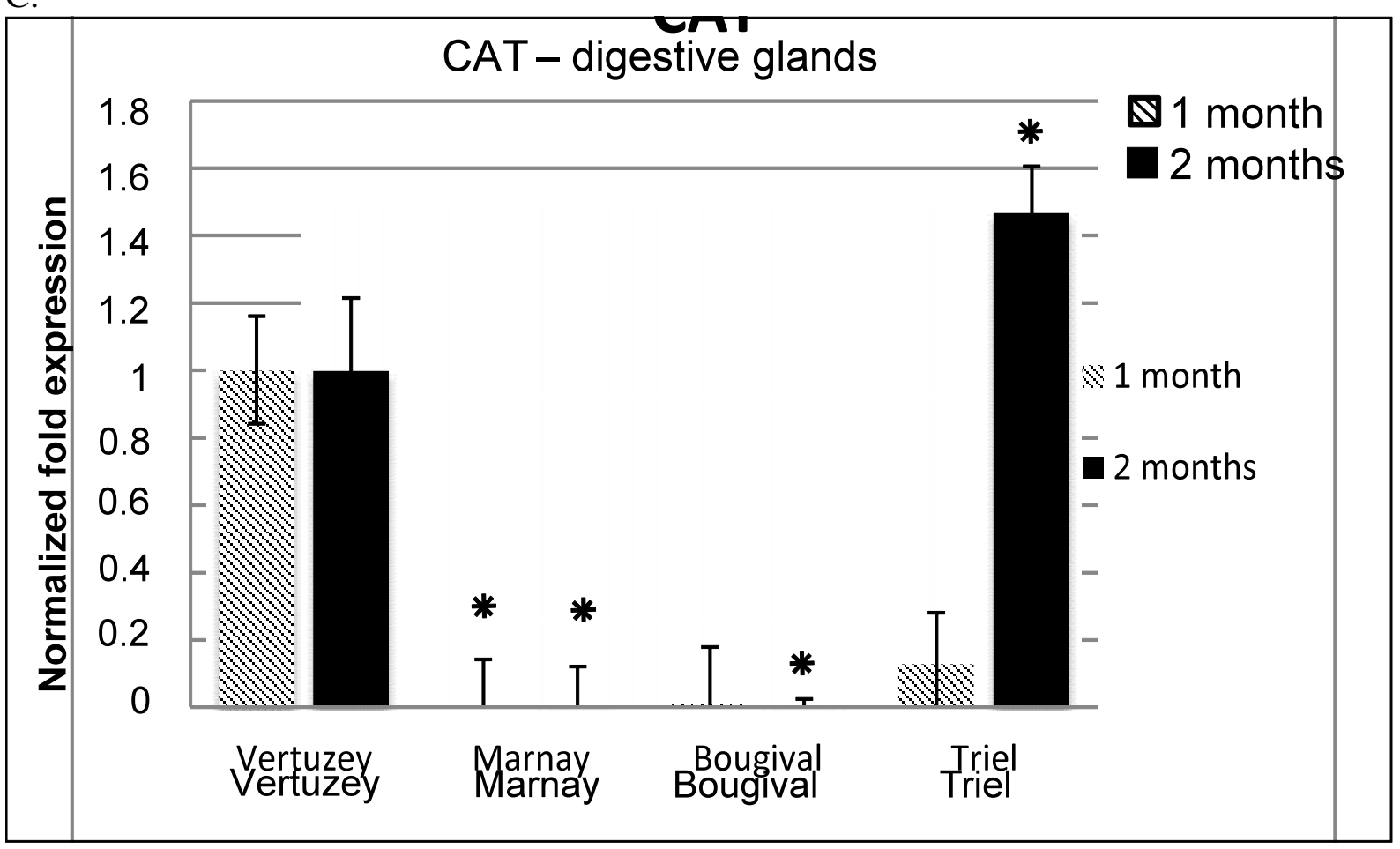

D. 


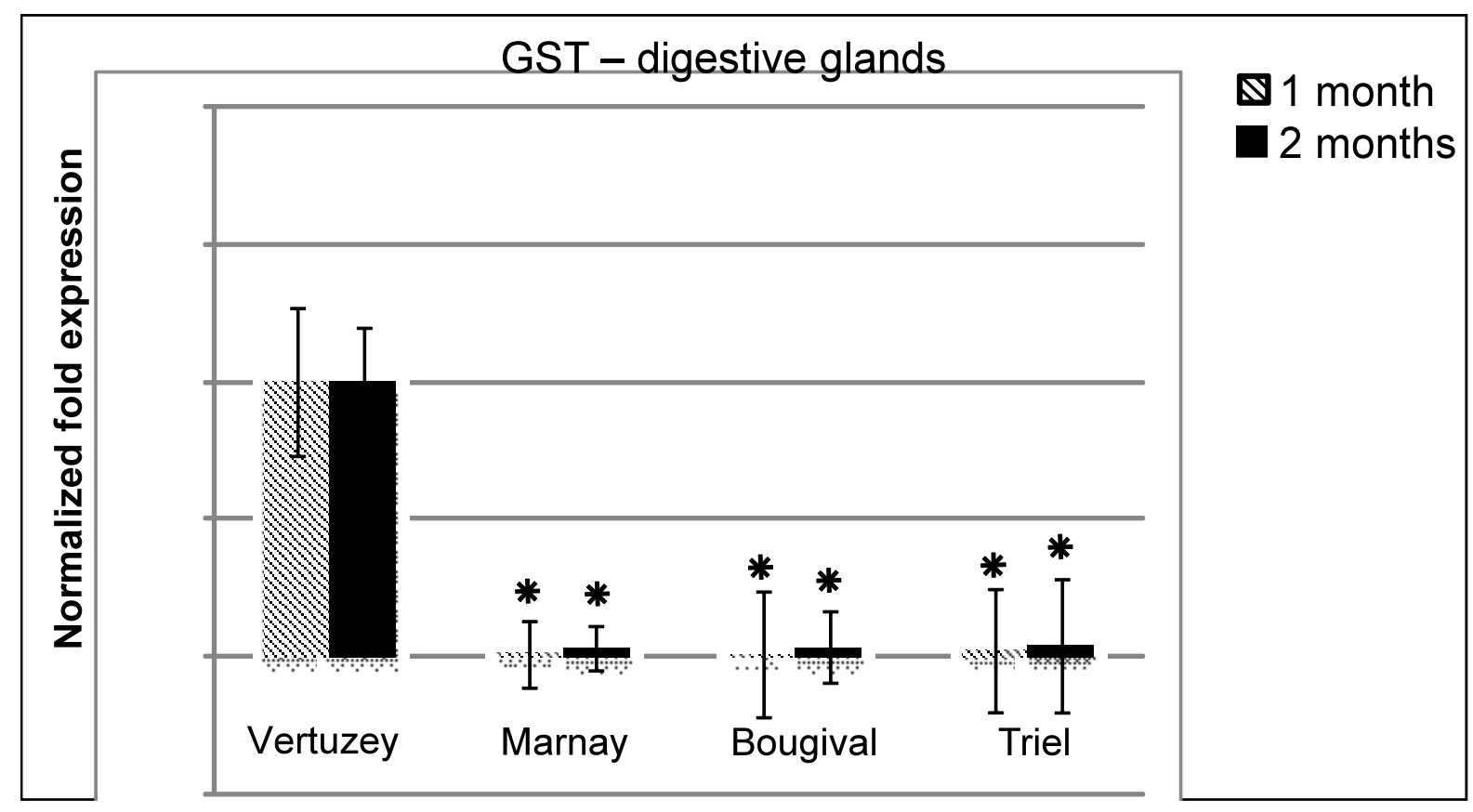

E.

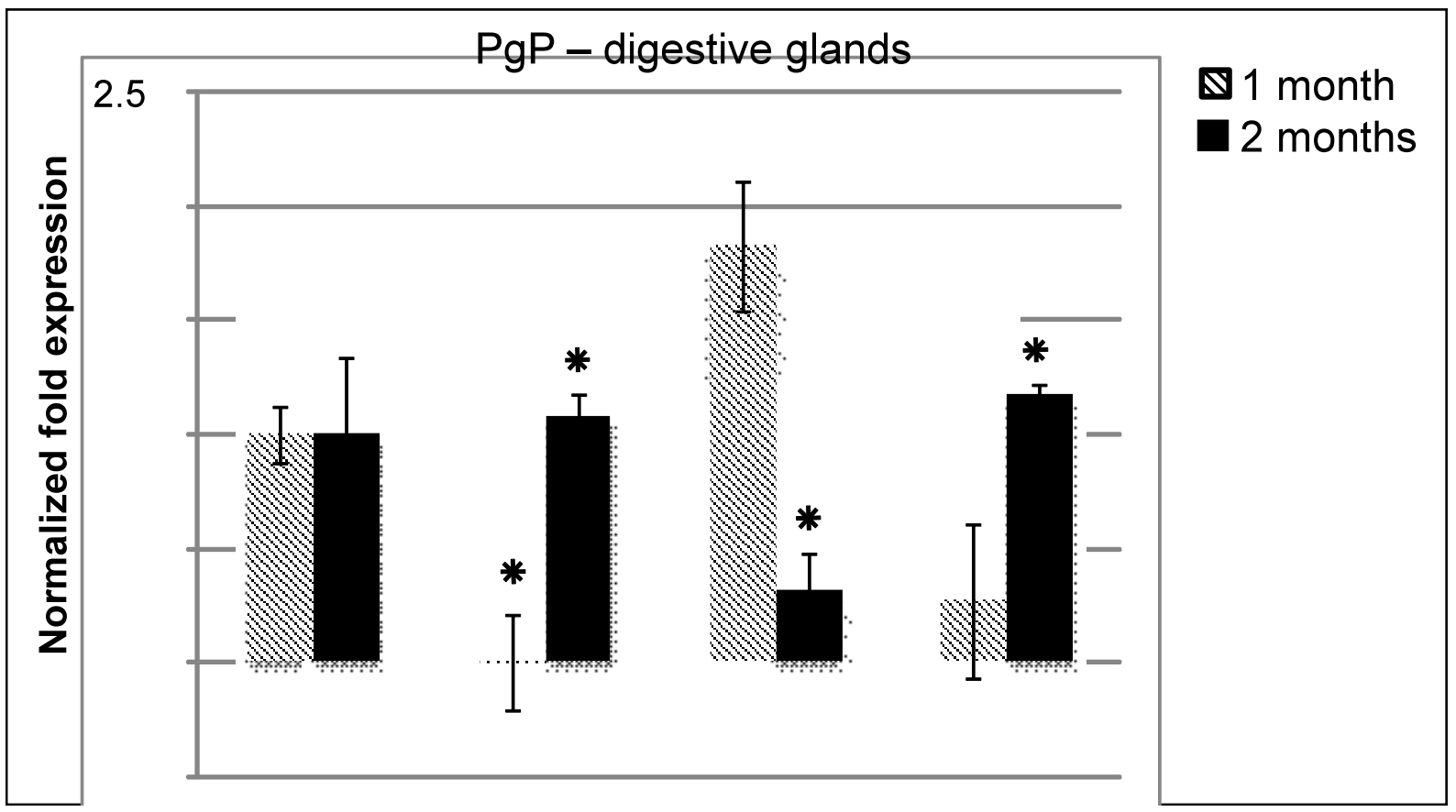

F. 


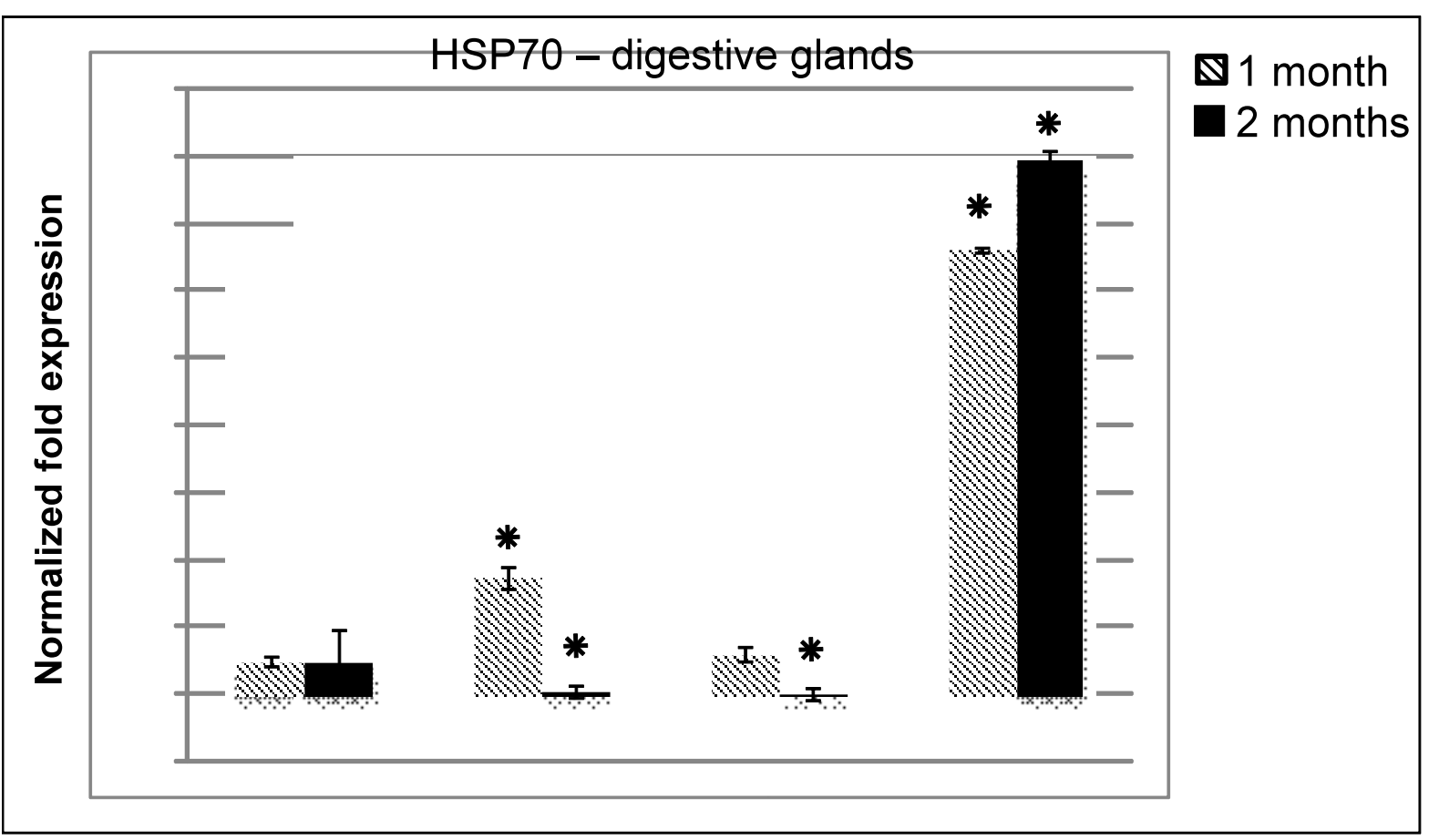

G.

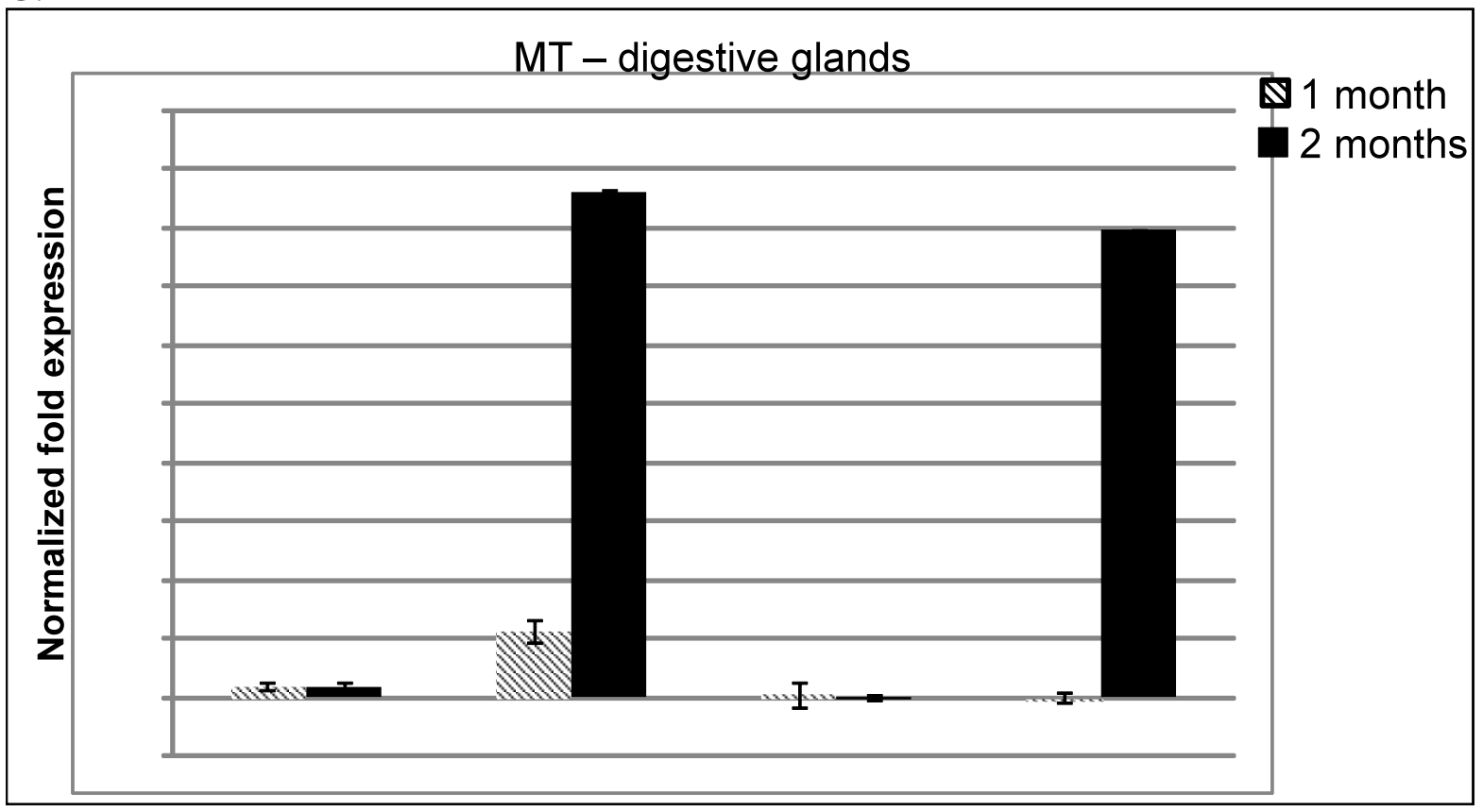


Table 2.

\begin{tabular}{|l|l|l|}
\hline Assay & Gills & Digestive glands \\
\hline ADDUCTS & $\begin{array}{l}\text { Bougival>>Marnay> Triel } \\
\text { Increase after 2 months }\end{array}$ & $\begin{array}{l}\text { Marnay> Triel> Bougival } \\
\text { Increase (except Marnay) }\end{array}$ \\
\hline AHR & $\begin{array}{l}\text { Bougival>Marnay=Triel } \\
\text { Increase after 2 months }\end{array}$ & inhibited \\
\hline SOD & $\begin{array}{l}\text { Decrease vs Verturzey } \\
\text { (reincrease at Marnay 2 } \\
\text { months) }\end{array}$ & $\begin{array}{l}\text { Decrease } \\
\text { (marnay=Triel>>bougival) }\end{array}$ \\
\hline CAT & Decrease & $\begin{array}{l}\text { Decrease Marnay \& Bougival } \\
\text { Increase Triel }\end{array}$ \\
\hline GST & Increase only Marnay & decrease \\
\hline PgP & $\begin{array}{l}\text { Increase only after 1 month } \\
\text { bougival }\end{array}$ & $\begin{array}{l}\text { No significative variation } \\
\text { HsP70 }\end{array}$ \\
$\begin{array}{l}\text { Increase only after 1 month } \\
\text { Marnay> Bougival=Triel }\end{array}$ & $\begin{array}{l}\text { Increase at marnay after 1 } \\
\text { month only } \\
\text { High increase at Triel }\end{array}$ \\
\hline MT & Decrease & Increase Marnay \& Triel \\
\hline
\end{tabular}

